\title{
NON PERFORMING LOANS MANAGEMENT IN JAPAN DURING BABURU KEIZAI, 1989-2001
}

\author{
Wong Mee Hui, Alias Abdullah and Zakaria Mustafa
}

\section{Introduction}

Japan has the third largest economy in the world after the United States and China. ${ }^{1}$ Japan's economy has experienced rapid growth and undergone changes in structure since the mid-19th century when the Meiji government opened the country to trade and Western influence for the first time. The Japanese economy also experienced "Baburu Keizai" which started from 1989 until 1992 because of the monetary policy mistake of the Japanese involvement in the Plaza Accord ${ }^{2}$ and also due to the low interest rate set by the Bank of Japan (BOJ). After the Baburu Keizai occured, Japan entered into the "Lost Decade" period which started from 1992 to 2001, representing Japan's prolonged economic downturn. Japan's economic growth slowed significantly in the 1990s during the "Lost Decade", caused by the effects of Japanese asset price bubble ${ }^{3}$ and national policies which removed excess investment from the stock and real estate market.

\section{Methodology}

This study used qualitative research methods based on primary and secondary data. In terms of secondary data, various materials were obtained from local libraries or Japanese libraries such as University of Malaya library, East Asian Library, Library Institute of Developing Countries, Japan External Trade Organization (IDE-JETRO), Komaba Library, the National Diet Library (Tokyo Main Library), University of

1 International Monetary Fund, World Economic Outlook Database, October 2010: Nominal GDP List of Countries, Washington: International Monetary Fund, 2010.

2 Plaza Accord was an agreement that benefitted the United States. The finance ministers and central bank presidents of four countries were involved in this agreement namely Japan, France, West Germany, England and the United States. The involvement of these five countries in the Plaza Accord in Plaza Hotel, New York was to work together to weaken the dollar exchange rate voluntarily. Thus, the objective of this agreement was to assist the United States to improve its trade deficit, especially against Japan and also as a stimulant for the economy to remove United States from the 1980s long economic recession. Plaza Accord was functioning well in the economy and reduce the deficit trade. The depreciation of the dollar was very good for the Unites States which remains the main currency used in foreign currencies trading and used in measuring the value of a country's currency. However, for the other four countries, their currencies fell more than the desired level. With this, the same five countries opted to cancel the Plaza Accord through the Louvre Accord in 1987 in Paris which saw the strengthening of the dollar again.

3 バブル景気 Japanese asset price bubble in Japan started from 1989 to 1992 through high property and stock prices. 
the United Nations Organisation Library, Kodaira City Library and the Library for Economic Research Center Japan. Primary data was collected through interviews with academics related to the study in japan and Malaysia. For example, this study obtained information Satoru Kumagai and Kozo Kunimune from IDE-JETRO and Yasuhiro Maehara from Hitotsubashi University in Japan between 18 September 2009 to 30 October 2009. Government documents were used extensively as reflected by Figure 1. Figure 1 shows that Japanese income and household spending was affected during the Asian economic crisis which began in 1997 and lasted till. This is because Japan's export sector was affected following the Asian economic crisis in which the problem of devaluation of the yen aggravated the country's total imports from the Asian region, as shown in Table 1.

Figure 1 Income and Expenditure Japanese from 1965 to 2006

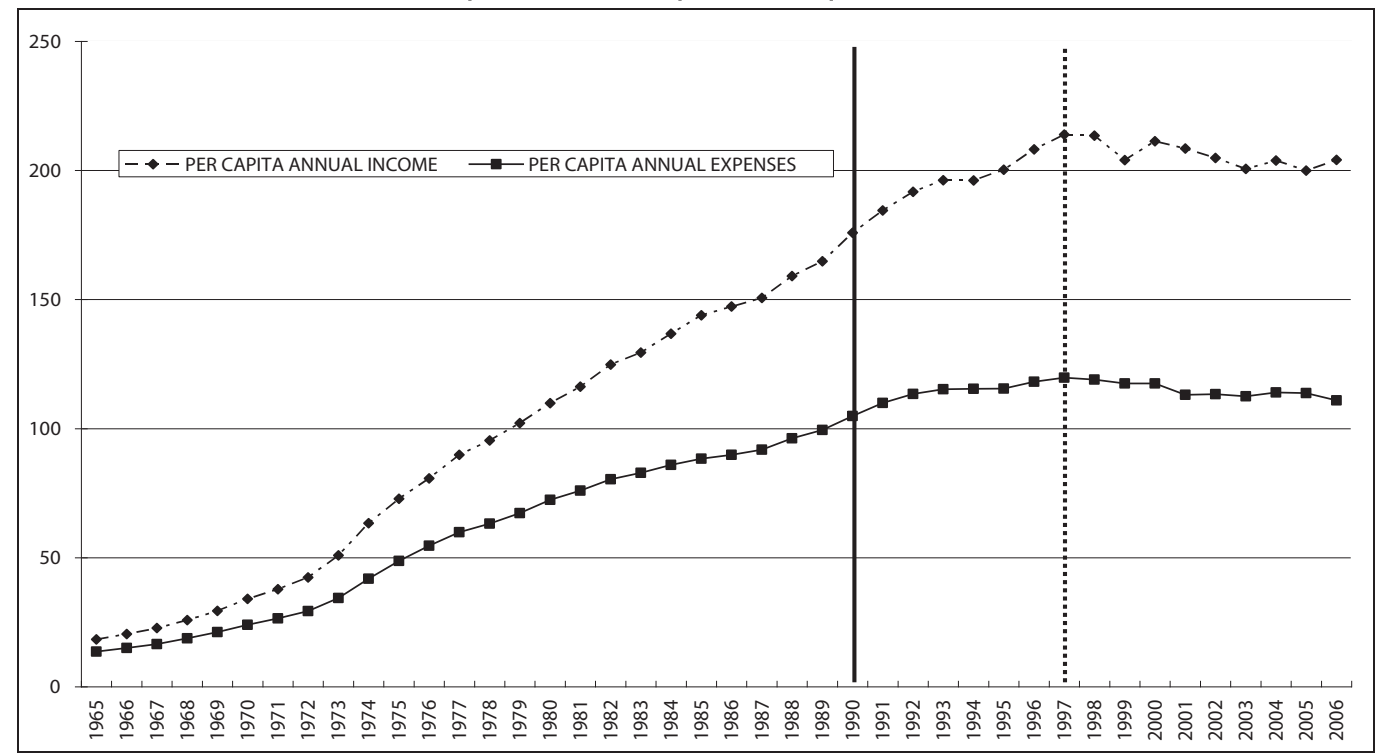

Source: Annual Report on the Family Income and Expenditure Survey 1985-2006, Ministry of Internal Affairs and Communications, Japan, 1965-2007.

A weaker yen resulted in the decline in imports of raw materials and light industrial goods from the Asian region which affected the export sector and economic growth of Japan. Shortage of raw materials and light industrial goods shortage made it difficult for Japan to produce manufactured goods such as steel, ships, automobiles, computer chips and consumer electronics for export. So, the reduction in export adversely affected not only the national income as shown in Figure 2, but equally the per capita income of households. Furthermore the hike in prices as a result of the weak yen resulted in a reduction in household expenses.

The overall GDP growth during the economic downturn in the 1990s only increased 1.38 percent from $¥ 440,124,900$ million in 1990 to $¥ 501,068,100$ million in 2000 , compared with growth in the 1980s, which increased more than 4 percent every year as shown in Figure 2. The growth rate has declined since 1998 and the unemployment rate rose from 2.1 percent in 1991 to 4.7 percent at the end of 2000. The increase in the unemployment 
Table 1 Sales Export to Japan (1996) ${ }^{4}$

\begin{tabular}{cc}
\hline Economy & Percentage \\
\hline Indonesia & 28.8 \\
China & 20.4 \\
Philippines & 17.1 \\
Thailand & 16.8 \\
Malaysia & 13.4 \\
South Korea & 12.3 \\
Taipei, China & $11.8(1995)$ \\
Singapore & 8.2 \\
Hong Kong, China & 6.5 \\
\hline
\end{tabular}

Source: Brooks, D. H., Felipe, J., Hasan, R., and Siregar, R. Y. , The Yen Depreciation and Its Implications for East and Southeast Asia, EDRC Briefing Notes Series No. 1, September, 1998. Retrieved November 19, 2009. http://www. docstoc.com/docs/68160234/THE-YEN-DEPRECIATION-AND-ITS-IMPLICATIONS-FOREAST-AND-SOUTHEAST-ASIA\#

Figure 2 GDP Growth Rate in Japan (1956-2008)

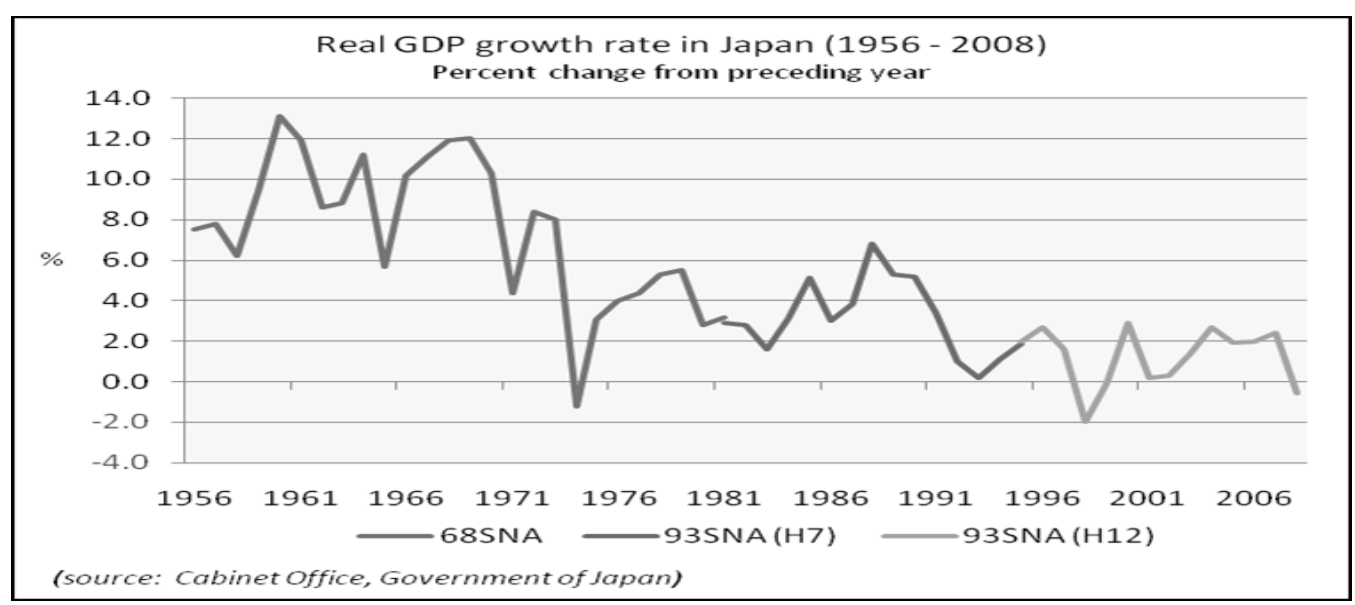

Source: En, W. S., Economy of Japan., 2010. Retrieved February 2, 2010, http://www.esri. cao.go.jp/ en/sna/ data.html\#qe.

rate to 4.7 percent is considered high as the unemployment rate in Japan never reached more than 2.8 percent in the 1980s.

\section{Results and Discussion}

Japanese Baburu Keizai became a reality when high investment growth occurred in the property sector and shares between 1989 to 2001 (see Figure 3). For example, share

4 Hong Kong and China did not depend on export of goods to Japan like the countries in East Asia and South East Asia. However, Hong Kong and China were very dependent on Japanese tourists who spent a lot in their countries. Unfortunately, the decline of the yen against the dollar value of Hong Kong resulted in reduction in spending by Japanese tourists. 
prices showed a sharp increase in the 1980s. The average volume of trade conducted during the late 1980s was more than one billion shares a day because of rising stock prices resulted in more companies and individuals trading in the stock market. Similarly, property prices increased between 1986 to 1993, first within the business district in the cities and then gradually the phenomenon spread to the rural areas.

Figure 3 Property prices and shares of the First Quarter 1980 to First Quarter of 2008

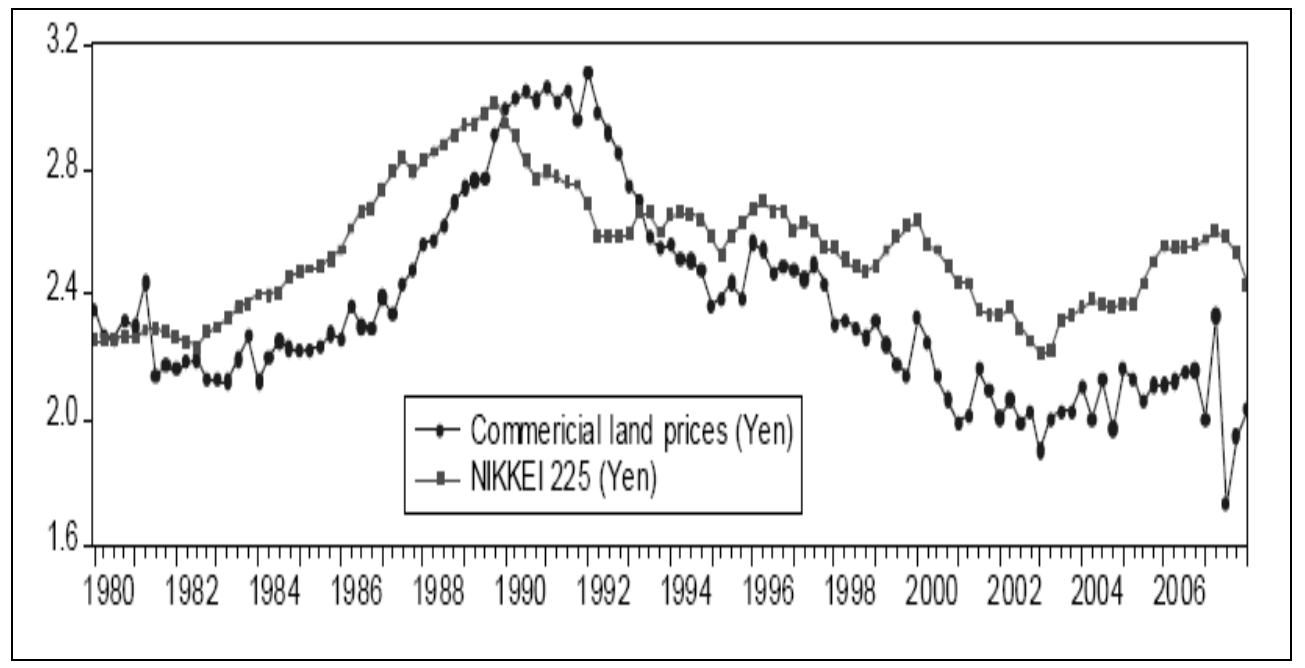

Source: Lee, E. H. , "Review of Fluctuations in Land and Stock Prices in the Japanese Economy.' The Korean Journal of Economics, Vol. 16, No.1, 2009, pp.95-122.

Conversely, research shows that between 1989 and 2001 saw the sharp fall of real estate and financial markets in Japan. The main factor leading to the existence of the Baburu Keizai in Japan which led to sharp decline in prices was the result of inappropriate financial policy management by the BOJ. Steps to sign the Plaza Accord in 1985 with the objective of overcoming the economic downturn in the United States indirectly increased the value of the yen and affected Japan's export sector (see Figure 4). Figure 4 shows that in the first half of the 1980s, the US Dollar (USD) was much stronger than the German Mark (DEM), French Francs (FRF), British Pounds (GBP) and the Japanese Yen (JPY). More interestingly, before and after the Plaza Accord, the USD suffered a decline.

For example, as shown in Table 2 and Figure 5, in 1985, the exchange rate between USD and the yen was US $\$ 1=¥ 236.79$, but in 1990 , the exchange rate of US $\$ 1=¥ 144.15$. This exchange rate clearly indicates increase in the value of the yen because after Baburu Keizai, US $\$ 1$ could only be converted to $¥ 144.15$. Though the yen became more valuable, but the exchange rate actually has a negative impact on exports. Yen appreciation affected not only the export sector but also the economic growth. The Japanese economy grew 4.4 percent in 1985 only to shrink to 2.9 percent in 1986. 
Figure 4 Shift in Foreign Exchange Rates (DEM / USD, FRF / USD, GBP /USD and JPY 9 USD) from January 1981 to December 1990

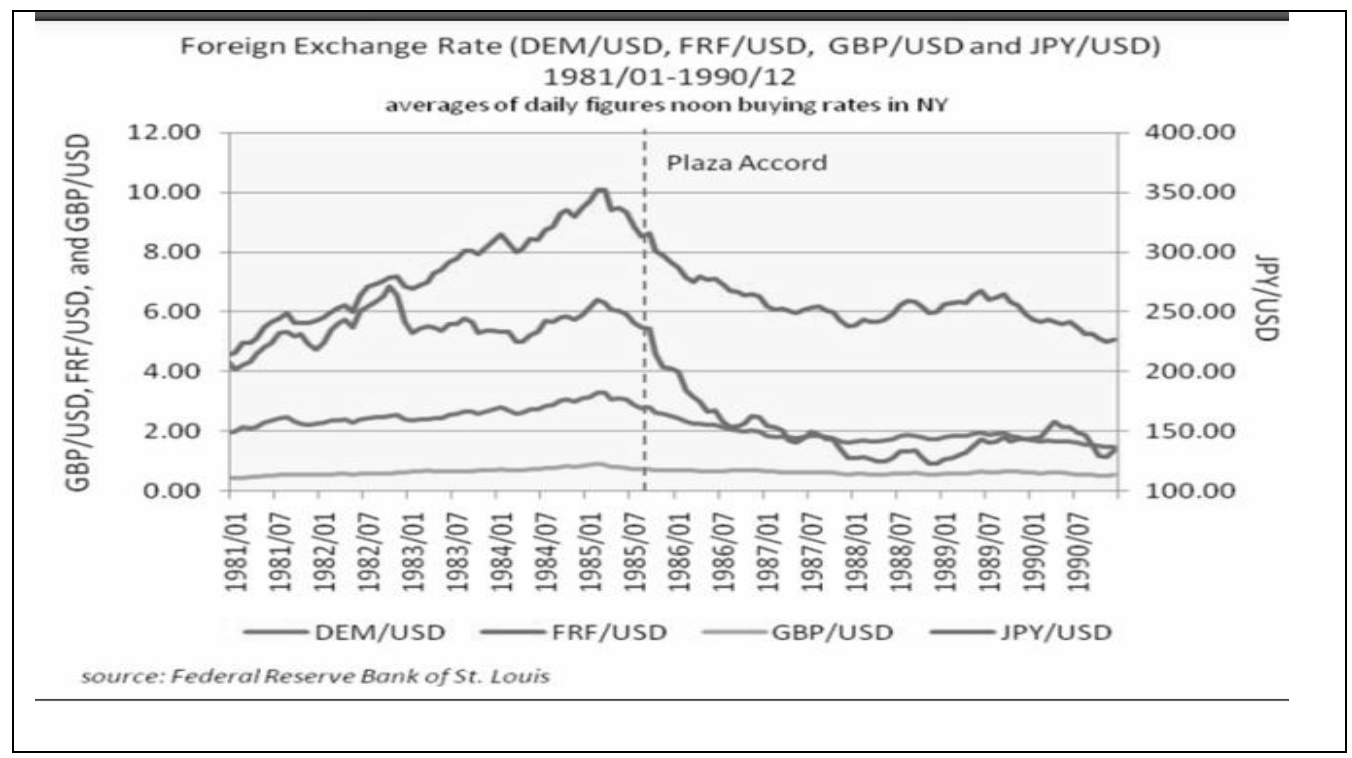

Source: Miyagawa, S., and Morita, Y., Lessons from Japan's Prolonged Recession, Tampere Economic Working Papers Net Series 44, September, 2005, Retrieved 2July , 2010.,http://www. researchgatenet/ publication/29678638_Lessons_from_Japan\%27s_prolonged_Recession.

Table 2 US Dollar Exchange Rate

\begin{tabular}{cc}
\hline Year & US dollar exchange \\
\hline 1955 & $¥ 360.00$ \\
1960 & $¥ 360.00$ \\
1965 & $¥ 360.00$ \\
1970 & $¥ 360.00$ \\
1975 & $¥ 297.26$ \\
1980 & $¥ 225.82$ \\
1985 & $¥ 236.79$ \\
1990 & $¥ 144.15$ \\
1995 & $¥ 122.78$ \\
2000 & $¥ 107.73$ \\
2005 & $¥ 110.01$ \\
\hline
\end{tabular}

Source: International Monetary Fund, Economy of Japan, 2010, Retrieved February 2, 2010, http:/ /www.imf. org/external/pubs/ft/weo/2006/01/data/dbcselm.cfm? G=2001.

In order to boost Japan's economic growth, the Japanese government introduced monetary policy solutions, adminstered by BOJ that were clearly inappropriate in the long run. Between January 1986 to February 1987, the BOJ lowered interest rates from 
Figure 5 Foreign Exchange Rates Japan / US

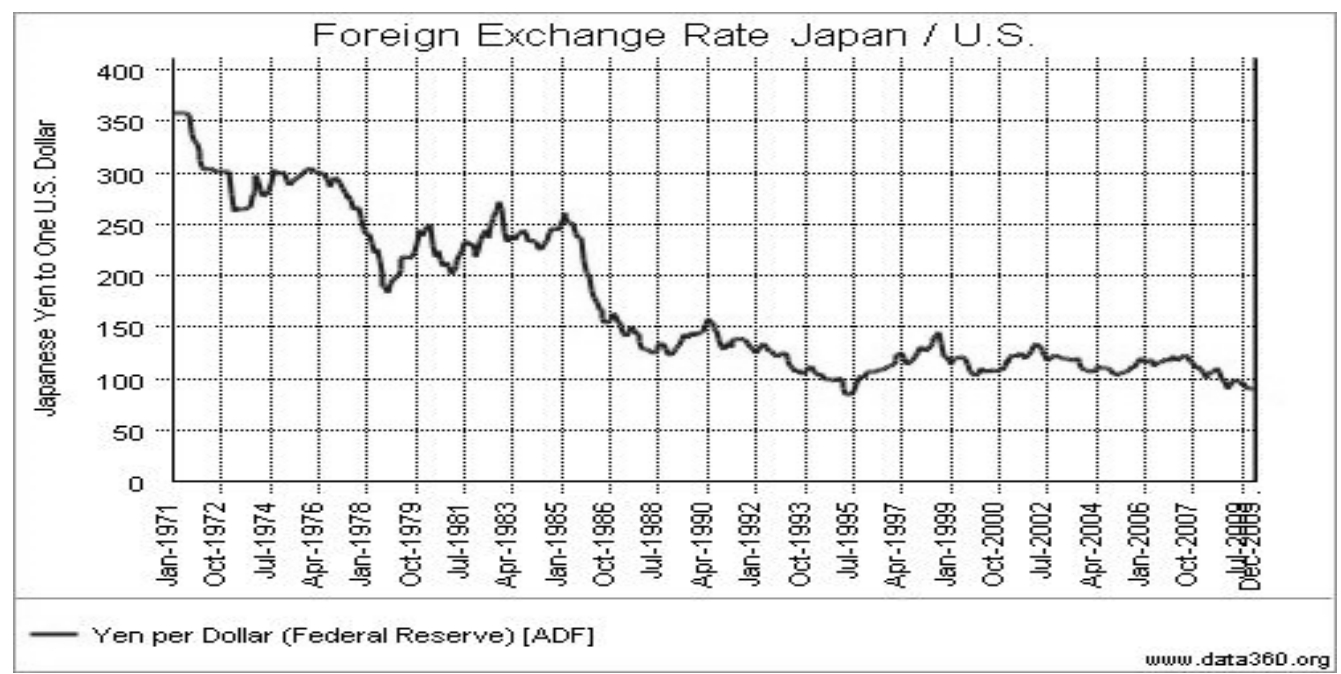

Source: Federal Reserve Bank of St. Louis, Japan/U.S. Foreign Exchange Rate, 2010, Retrieved 18 January , 2010, http:/ / research.stlouisfed.org/fred2/source?soid=1.

5 percent to 2.5 percent (see Table 3). The measure failed to restore Japan's economic growth. The Japanese government never expected that the action would lead to property market bubble in Japanese stock market which eventually led to a prolonged economic recession till 2001.

Table 3 Reduction of Interest Rates

\begin{tabular}{llc}
\hline \multicolumn{1}{c}{ Effective date } & Interest rate \\
\hline 30 January 1986 & 5.0 percent $\rightarrow 4.5$ percent \\
10 March 1986 & 4.5 percent $\rightarrow 4.0$ percent \\
21 April 1986 & 4.0 percent $\rightarrow 3.5$ percent \\
01 November 1986 & 3.5 percent $\rightarrow 3.0$ percent \\
23 Februari 1987 & 3.0 percent $\rightarrow$ 2.5 percent \\
\hline
\end{tabular}

Source: Okina, K., Shirakawa, M., and Shiratsuka, S., The Asset Price Bubble and Monetary Policy: Japan's Experience in the Late 1980s and the Lessons (Special Edition), Institute for Monetary and Economic Studies: Bank of Japan, 2001.

In addition, the analysis also found that Jusen, the mortgage company in Japan was a major contributing factor to the decline in Japan's Baburu Keizai. This is due the Jusen changing their business involvement in the more risky real estate loans in the 1980s. Rapid total property investment within Baburu Keizai whereby the lending of money by the Jusen from agricultural cooperatives became a factor that led to the fall of Baburu Keizai (See Table 4). This situation was exacerbated by the real estate lending by Jusen without strict controls provided by the Japanese legal system. As it is a well known fact, the Jusen is out of the control of MOF (see Table 5 and Table ). This eventually contributed to the fall of Baburu Keizai in Japan in 1992. 
Table 4 Loans to 7 Jusen $^{5}$ by agricultural cooperatives

(¥ billion)

\begin{tabular}{cccc}
\hline Year & Sinren & Nochu & Kyosairen \\
\hline 1980 & 70 & 1417 & 3434 \\
1985 & 2725 & 2585 & 5697 \\
1986 & 3388 & 3322 & 6130 \\
1987 & 4283 & 4617 & 6792 \\
1988 & 6287 & 5046 & 7446 \\
1989 & 12268 & 6484 & 10287 \\
1990 & 26701 & 8386 & 13514 \\
1991 & 34354 & 8235 & 13838 \\
\hline
\end{tabular}

Source: Kataoka, T., Bank Crisis: Its Causes and Results, 1996, Retrieved February 10, 2010, http:/ /www2.bus. osaka-cu.ac.jp/ kataoka/bcrisis/\#1-2.

Table 5 Housing Loan

\begin{tabular}{|c|c|c|c|c|c|c|}
\hline Year & $\begin{array}{c}\text { Larger } \\
\text { bank }\end{array}$ & City bank & $\begin{array}{c}\text { Regional } \\
\text { banks }\end{array}$ & $\begin{array}{c}\text { Housing } \\
\text { loan } \\
\text { corporation* }\end{array}$ & 8 JUSEN $^{* *}$ & Total $^{* * *}$ \\
\hline 1980 & 168,879 & 60,313 & 53,508 & 106,884 & 31,023 & 412,257 \\
\hline 1985 & 202,020 & 82,463 & 62,205 & 212,157 & 50,432 & 595,927 \\
\hline 1986 & 231,154 & 100,505 & 64,228 & 230,345 & 55,280 & 644,808 \\
\hline 1987 & 274,757 & 133,519 & 71,416 & 254,498 & 65,678 & 727,204 \\
\hline 1988 & 315,506 & 166,217 & 77,416 & 288,482 & 72,939 & 816,050 \\
\hline 1989 & 370,788 & 209,808 & 82,804 & 323,187 & 93,150 & 938,696 \\
\hline 1990 & 408,557 & 237,758 & 88,497 & 359,529 & 125,273 & $1,061,319$ \\
\hline 1991 & 433,133 & 250,527 & 94,528 & 386,583 & 126,225 & $1,131,907$ \\
\hline
\end{tabular}

Source: Kataoka, T., Bank Crisis: Its Causes and Results, 1996, Retrieved February 10, 2010, http:/ /www2. busOsaka-cu. ac.jp/ kataoka/bcrisis/\#1-2.

Note: * Housing loan corporation are government institutions that specialize in housing loans.

**8 Jusen are Nihon Jutaku Kinyu, Jutaku Loan Service, Juso, Soga Jukin, Daiichi Jukin, Nippon Housing Loan, Chigin Seiho Jutaku Loan and Kyodo Jutaku Loan.

***Total includes credit unions, credit cooperatives, agricultural cooperatives, insurance companies and labor credit associations.

The most obvious effect on Japan's economic growth following the fall of the Japanese Baburu Keizai is the financial crisis that occurred in Japan in 1997. Japanese Baburu Keizai fall condition resulted in increasing non performing loans (NPL) problem as shown in Table 7. The sharp increase in NPL became extremely alarming, with 40 percent in 1991 to 75 percent in 1995 which led to increased funding costs for Japanese

57 Jusen are Nihon Jutaku Kinyu, Jutaku Loan Service, Juso, Soga Jukin, Daiichi Jukin, Nippon Housing Loan and Chigin Seiho Jutaku Loan. 
Table 6 The Composition of the 7 Jusen

(¥ billion)

\begin{tabular}{ccc}
\hline Year & Private house & Companies \\
\hline 1980 & 31,709 & 1,463 \\
1985 & 32,350 & 15,941 \\
1986 & 28,296 & 26,467 \\
1987 & 25,106 & 39,087 \\
1988 & 23,183 & 50,407 \\
1989 & 24,599 & 77,637 \\
1990 & 26,518 & 97,312 \\
1991 & 26,423 & 95,731 \\
\hline
\end{tabular}

Source: Kataoka, T., Bank Crisis: Its Causes and Results, 1996, Retrieved February 10, 2010, http://www2.bus. Osaka-cu. ac.jp/ kataoka/bcrisis/\#1-2.

Table 7 Non-Performing Loans (NPLs) of the seven Jusen, March 1995

\begin{tabular}{lcc}
\hline \multicolumn{1}{c}{ Jusen } & Total (billion) & \% of loan portfolio \\
\hline Nihon Jutaku Kinyu & $¥ 1,300$ & 68.9 \\
Diichi Jutaku Kinyu & $¥ 742$ & 49.0 \\
Nihon Housing Loan & $¥ 1,300$ & 57.6 \\
Juso & $¥ 666$ & 41.0 \\
Jutaku Loan Service & $¥ 1,000$ & 70.4 \\
Sogo Jukin & $¥ 716$ & 63.4 \\
Chigin Seiho Jutaku Loan & $¥ 408$ & 46.2 \\
\hline Total & $¥ 6140$ & \\
\hline
\end{tabular}

Source: Oguni, K., Furyoo Saiken Shori no Seijikeizaigaku (The Political Economy of Bad Loan Cleanup), Tokyo: Heigensha, 1995.

banks in Europe and the United States. In addition, the strongest banking institution in Japan had to pay the risk premium ${ }^{6}$ for lending transactions in the financial system.

More significantly, by the end of 1997, the fall of Japanese Baburu Keizai also caused the failure of financial institutions in Japan as shown in Table 8. Table 8 indicates that more than 170 saving institutions in Japan began to fail starting from 1991 with most of them failing in the mid-1990s. Japan's economic situation saw temporary recovery in 2000. But as a result of the continued NPL collection activities, the capital position of banks were always threatened.

Continuation accumulation of NPLs in the financial system in Japan almost destroyed the capital position of Japanese banks (regardless of the small amount of profit made until 2009 as shown in Table 9 and Figure 6. With reference to Table 9 and Figure 6, bank losses as a result of Japan's NPL problem started from a small amount of

6 Known as Japanese financial premium that is a form of additional interest charges imposed on international lending by Japanese banks. 
Table 8 Number of Saving Institutions Bankruptcy ${ }^{7}$

\begin{tabular}{ccccc}
\hline Year & Banks* $^{*}$ & Shinkin banks & Credit cooperatives & Total \\
\hline 1990 & 0 & 0 & 0 & 0 \\
1991 & 1 & 0 & 0 & 1 \\
1992 & 0 & 1 & 0 & 1 \\
1993 & 0 & 1 & 1 & 2 \\
1994 & 1 & 0 & 4 & 5 \\
1995 & 1 & 0 & 5 & 6 \\
1996 & 2 & 3 & 3 & 8 \\
1997 & 5 & 0 & 7 & 12 \\
1998 & 3 & 1 & 31 & 35 \\
1999 & 5 & 6 & 15 & 26 \\
2000 & 1 & 5 & 27 & 33 \\
$2001^{* *}$ & 1 & 9 & 37 & 47 \\
\hline Total & 20 & 26 & 130 & 176 \\
\hline
\end{tabular}

Source: Hanazaki, M., and Horiuchi, A., "A Review of Japan's Bank Crisis from the Governance Perspective,' Pacific-Basin Finance Journal, 11, 2003,pp. 305-325.

Note: * This area includes the city banks, regional banks I and II, trust banks and long-term credit banks.

** Figures for the year 2001 up to November.

bank losses in 1993 to more than $¥ 96$ trillion which amounted to 19 percent of Japan’s GDP in 2005. ${ }^{8}$ Starting from 2003, the amount of NPLs saw a reduction (see Table 10). Though the Japan Services Agency announced in mid-2005 that the Japanese NPL crisis was officially over, ${ }^{9}$ the problem of accumulation of huge losses on loans continued.

This is because the services of lending to production companies, especially SME encountered losses starting from 2000. As a result, the total profits of Japanese banks were very low due to bank profits used to curb the problem of NPLs. In addition, the fall in Japanese stock prices was also another motivating factor (see Figure 7). In the meantime, Japanese banks did not have a lot of net capital to ensure the soundness of Japanese banks. Liabilities of the Japanese banking sector reached 3 to 4 percent, as shown in Figure 8. Total bank losses continued to rise to $¥ 97$ trillion, almost 20 percent of Japan's GDP in 2007, as shown in Figure 6. In 2009, the total losses accumulation suffered by Japanese banks since 1992 reached more than $¥ 102$ trillion or about 20 percent of Japan's GDP.

7 Table 8 includes the failed banks managed by the government and private sectors. For example, in October 1994, Mitsubishi Bank saved Nippon Trust Bank from failure when the government did not offer any financial assistance.

8 Financial Services Agency, http://www.fsa.go.jp

9 Hutchison, M. M., Ito, T., and Westermann, F. (2005). The Great Japanese Stagnation: Lessons for Industrial Countries, Economic Policy Research Unit Working Paper Series 05-13, December, 2005. Retrieved June 26, 2010. Website: (http:/ / www.econ.ku.dk/epru/

files/wp/wp-05-13.pdf) 
Table 9 Loan losses in Japan

(¥ Trillion)

\begin{tabular}{cccc}
\hline Date & Loan losses & $\begin{array}{c}\text { Cumulative loan losses since } \\
4 / 1992\end{array}$ & The number of major banks \\
\hline $3 / 1994$ & 3.872 & 5.512 & 21 \\
$3 / 1995$ & 5.232 & 10.744 & 21 \\
$3 / 1996$ & 13.369 & 24.113 & 20 \\
$3 / 1997$ & 7.763 & 31.877 & 20 \\
$3 / 1998$ & 13.258 & 45.135 & 20 \\
$3 / 1999$ & 13.631 & 58.766 & 17 \\
$3 / 2000$ & 6.944 & 65.71 & 18 \\
$3 / 2001$ & 6.108 & 71.818 & 18 \\
$3 / 2002$ & 9.722 & 81.54 & 15 \\
$3 / 2003$ & 6.658 & 88.198 & 13 \\
$3 / 2004$ & 5.374 & 93.572 & 13 \\
$3 / 2005$ & 2.848 & 96.42 & 13 \\
$3 / 2006$ & 0.363 & 96.783 & 11 \\
$3 / 2007$ & 1.046 & 97.829 & 11 \\
$3 / 2008$ & 1.124 & 98.953 & 11 \\
$3 / 2009$ & 3.094 & 102.046 & 11 \\
\hline
\end{tabular}

Source: Hoshi, T., and Kashyap, A. K., Will the U.S. Bank Recapitalization Succeed? Eight Lessons from Japan, NBER Working Paper No. 14401, August, 2009, Retrieved August 08, 2010, http:/ / www.nber.org/papers/ w14401.

Figure 6 The NPL losses Bank of Japan Approaching 20 Percent of Japan's GDP

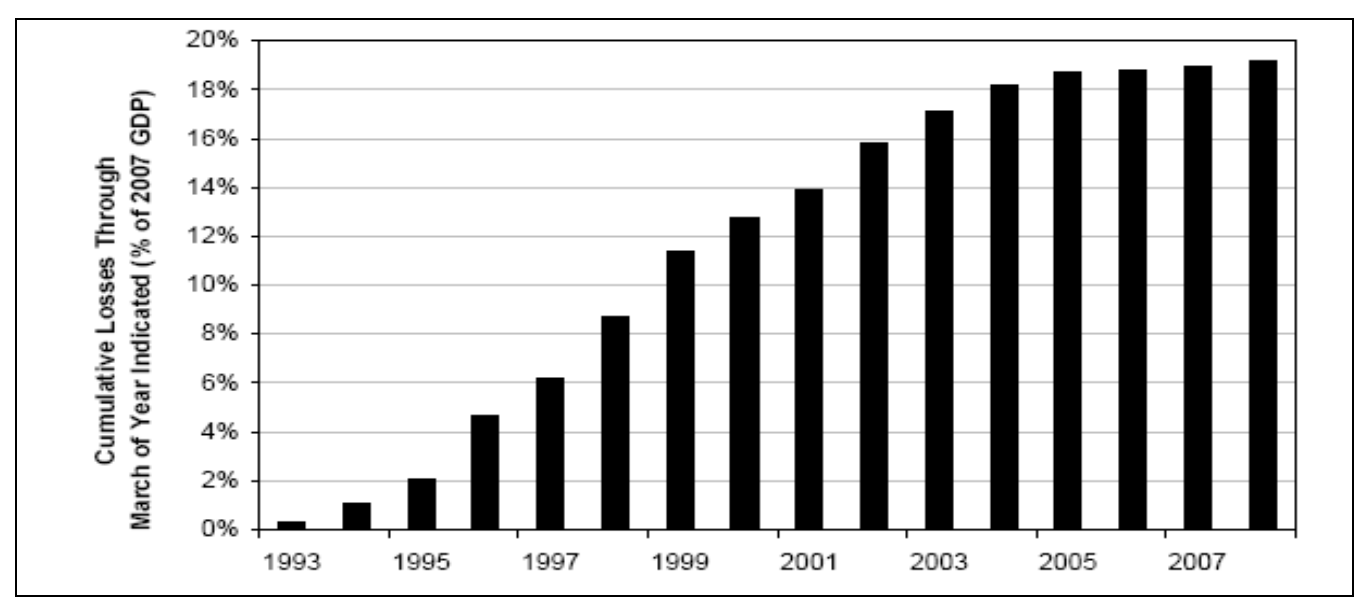

Source: Koo, R., and Sasaki, M, Japan's Disposal of Bad Loans: Failure or Success? NRI Papers No. 151, March 01, 2010. Retrieved March 08, 2010, http://www.nri.co.jp/english/opinion/papers/2010/pdf/np2010151.pdf. 
Table 10 Self Assessment Assets Revenue Transition by Bank

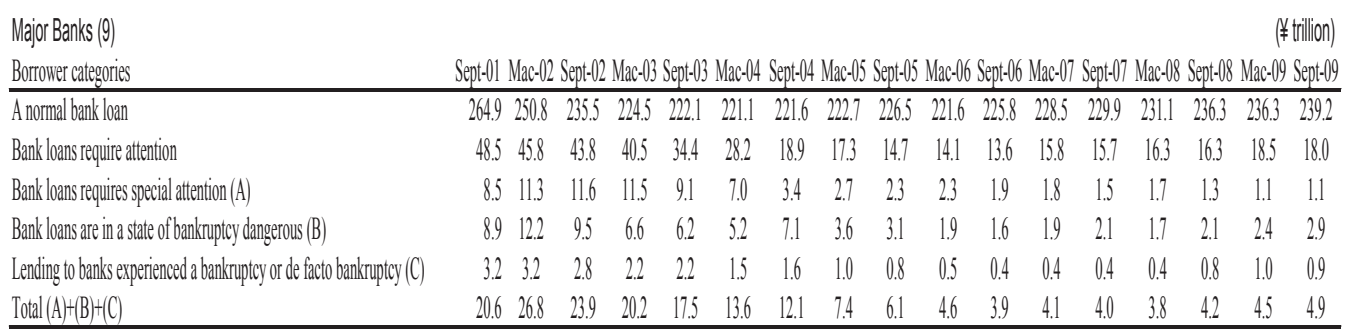

Regional Banks (109)

(Itinilion)

Borrower categories

Sept-01 Mac-02 Sept-02 Mac-03 Sept-03 Mac-04 Sept-04 Mac-05 Sept-05 Mac-06 Sept-06 Mac-07 Sept-07 Mac-08 Sept-08 Mac-09 Sept-09

A normal bank loan

$\begin{array}{lllllllllllllllll}135.5 & 136.2 & 134.4 & 141.0 & 140.0 & 142.7 & 142.2 & 146.8 & 147.4 & 152.2 & 153.8 & 156.4 & 156.9 & 159.3 & 159.3 & 162.2 & 153.6\end{array}$

Bank loans require attention

$\begin{array}{lllllllllllllllll}34.2 & 32.9 & 31.0 & 30.1 & 28.0 & 26.5 & 24.8 & 23.7 & 23.1 & 22.9 & 23.1 & 24.2 & 24.6 & 25.2 & 25.8 & 27.8 & 28.5\end{array}$

Bank loans requires special attention (A)

$\begin{array}{lllllllllllllllll}4.2 & 4.6 & 4.8 & 4.9 & 4.5 & 4.1 & 3.6 & 3.1 & 2.8 & 2.4 & 2.3 & 2.1 & 2.0 & 2.0 & 2.0 & 1.0 & 1.1\end{array}$

Bank loans are in a state of bankkuptcy dangerous (B)

$\begin{array}{lllllllllllllllll}6.1 & 6.4 & 6.5 & 6.3 & 6.0 & 5.8 & 5.5 & 5.1 & 4.8 & 4.4 & 4.4 & 4.1 & 4.1 & 4.0 & 4.1 & 4.0 & 3.9\end{array}$

Lending to banks experienced a bankruptcy or de facto bankruptcy (C)

$\begin{array}{lllllllllllllllll}4.0 & 3.9 & 3.8 & 3.5 & 3.4 & 2.8 & 2.5 & 2.2 & 2.0 & 1.8 & 1.8 & 1.7 & 1.6 & 1.6 & 1.9 & 2.2 & 2.1\end{array}$

$\operatorname{Total}(A)+(B)+(C)$

\begin{tabular}{lllllllllllllllll}
14.2 & 14.8 & 15.0 & 14.7 & 13.9 & 12.8 & 11.6 & 10.4 & 9.7 & 8.7 & 8.4 & 7.8 & 7.8 & 7.6 & 8.0 & 7.2 & 7.0 \\
\hline
\end{tabular}

All Bank (120)

(\#trillion)

Borrower categories

Sept-01 Mac-02 Sept-02 Mac-03 Sept-03 Mac-04 Sept-04 Mac-05 Sept-05 Mac-06 Sept-06 Mac-07 Sept-07 Mac-08 Sept-08 Mac-09 Sept-09

A normal bank loan

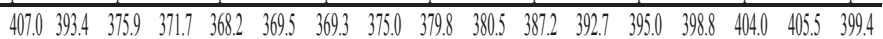

Bank loans seequire attention

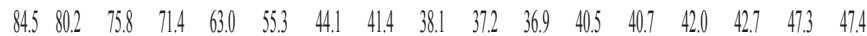

Bank loans requires special attention (A)

$\begin{array}{lllllllllllllllll}13.5 & 16.5 & 16.8 & 16.6 & 13.7 & 11.1 & 7.0 & 5.9 & 5.1 & 4.7 & 4.2 & 3.9 & 3.5 & 3.7 & 3.3 & 2.1 & 2.2\end{array}$

Bank loans are in a state of bankruptcy dangerous (B)

$\begin{array}{lllllllllllllllll}15.8 & 19.3 & 16.4 & 13.0 & 12.3 & 11.2 & 12.7 & 8.9 & 8.0 & 6.3 & 6.0 & 6.1 & 6.3 & 5.7 & 6.2 & 6.5 & 6.8\end{array}$

Lending to banks experienced a bankruptcy or de facto bankruptcy (C)

$\begin{array}{lllllllllllllllll}7.4 & 7.4 & 6.9 & 5.7 & 5.6 & 4.3 & 4.1 & 3.2 & 2.8 & 2.4 & 2.2 & 2.1 & 2.1 & 2.0 & 2.8 & 3.4 & 3.2\end{array}$

Total $(A)+(B)+(C)$

\begin{tabular}{lllllllllllllllll}
36.6 & 43.2 & 40.1 & 35.3 & 31.6 & 26.6 & 23.8 & 17.9 & 15.9 & 13.4 & 12.4 & 12.0 & 11.9 & 11.4 & 12.3 & 12.0 & 12.2 \\
\hline
\end{tabular}

Saving Financial Institutions (614)

(\#trillion)

Borrower categories

Sept-01 Mac-02 Sept-02 Mac-03 Sept-03 Mac-04 Sept-04 Mac-05 Sept-05 Mac-06 Sept-06 Mac-07 Sept-07 Mac-08 Sept-08 Mac-09 Sept-09

A normal bank loan

Bank loans require attention

Bank loans requires special attention (A)

Bank loans are in a state of bankruptcy dangerous (B)

Lending to banks experienced a bankruptey or de facto bankruptcy $(\mathrm{C})$

$\operatorname{Total}(A)+(B)+(C)$

$\left.\begin{array}{|c|c|c|c|c|c|c|c|}\hline 487.3 & 465.3 & 459.6 & 463.7 & 472.8 & 481.1 & 485.1 & 491.8 \\ 100.0 & 90.5 & 72.6 & 57.2 & 52.3 & 55.8 & 57.8 & 65.2 \\ 19.1 & 19.2 & 13.0 & 7.5 & 6.0 & 5.0 & 4.7 & 2.6 \\ 23.8 & 17.4 & 15.3 & 12.5 & 9.7 & 9.3 & 9.0 & 9.5 \\ 11.2 & 9.0 & 7.2 & 5.6 & 4.4 & 4.0 & 3.9 & 5.5 \\ 54.2 & 45.6 & 35.5 & 25.6 & 20.2 & 18.3 & 17.5 & 17.6\end{array}\right]$

Source: Financial Services Agency, Status of Non-Performing Loans, 2010, Retrieved July 02, 2010, http:/ /www.fsa.go. jp/en/regulated/npl/20100205/07.pdf.

Note: 1. "Major banks" refer to City Banks, Trust Banks and former Japanese Industrial Banks.

2. Starting from March 2003, "Regional Banks" included Bank Saitama Resona.

3. The figures for "All Banks" is composed of City Banks, the former Long-Term Credit Banks (including Shinsei Bank from September 2004 sustainability which has changed its position to the Ordinary Bank Charter on 1 April 2004 and including Aozora Bank from September 2006 continued to remain change its position to the Ordinary Bank Charter on 1 April 2006), Trust Banks and Regional Banks (including Saitama Resona Bank from March 2003).

4. The figures in Table 10 from September 2003 to September 2005 for Mizuho Financial Group includes the NPL has been moved to a subsidiary to restore corporation. Starting from March 2003 to remain continuous, the figure for the United Financial of Japan (UFJ) (starting from March 2006 to remain continuous, Bank of Tokyo-Mitsubishi UFJ) is included in NPLs was transferred to a subsidiary to restore the corporation. Starting from March 2004 to remain continuous, the figures for Nishi-NIPPON Bank and Fukuoka City Bank (after March 2005, Nishi-NIPPON City Bank of the merger of the Nishi-NIPPON Bank and Fukuoka City Bank was formed) is included in NPLs has been transferred to the subsidiary to restore the corporation. Starting from March 2005 to remain continuous, the figures for Hokuriku Bank include NPLs were transferred to a subsidiary to restore the corporation. Starting from September 2005 to September 2008, figures for Shinwa Bank include NPLs were transferred to a subsidiary to restore the corporation. Starting from March 2008 to remain continuous, the figures for Towa Bank include NPLs were transferred to a subsidiary to restore the corporation. Starting from March 2009, figures for Hokuto Bank and Fukuoka Bank are included in NPLs has been transferred to a subsidiary to restore the corporation.

5. The figures in parentheses is the number of financial institutions that have been targeted in September 2009. 
Figure 7 Japanese Banking Sector Gains Affected by NPLs and Share's Losses

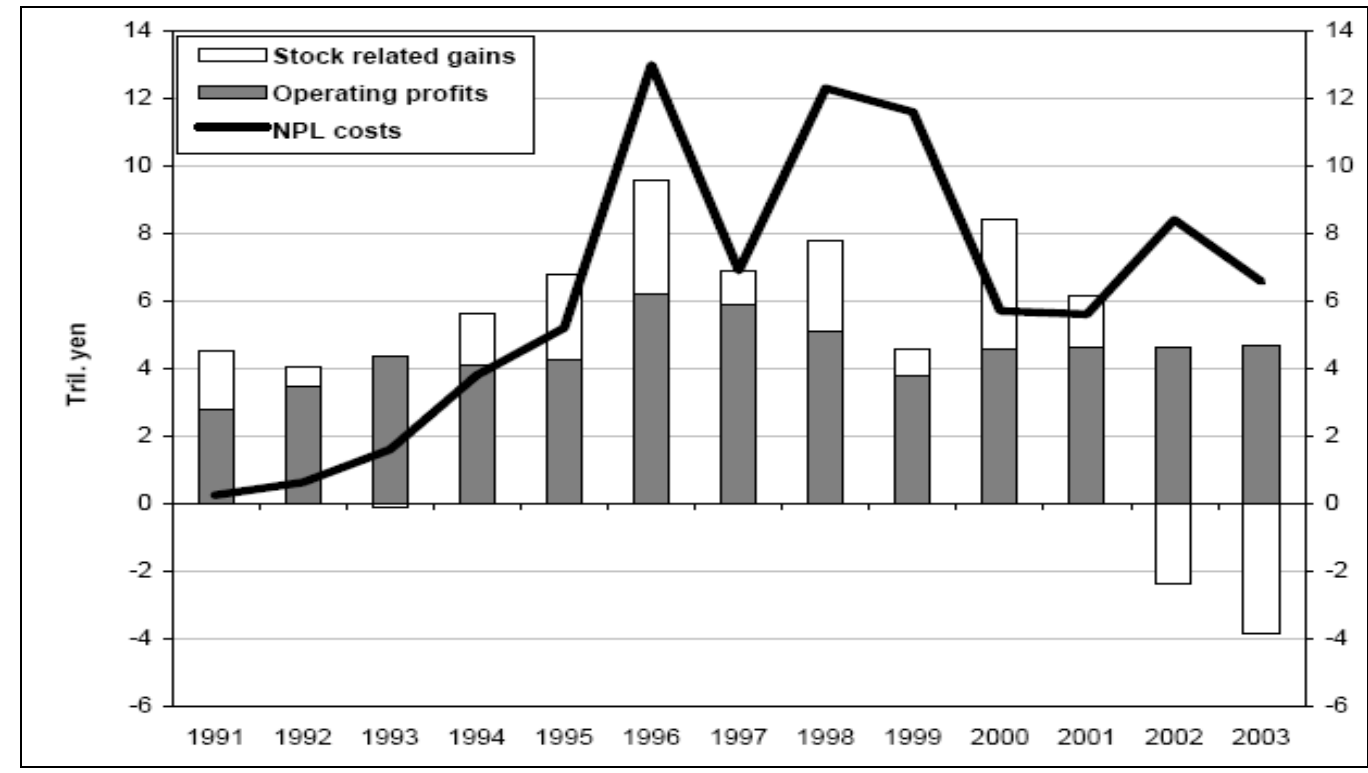

Source: Katz, R., Lessons for US from Japan's Banking Crisis, The Oriental Economist Report No. 212-8684380, March 19, 2009, Retrieved 27 June, 2010, http:/ / www.orientaleconomist.com/sitebuildercontent/ sitebuilderfiles/oversight_testimony.Pdf.

Figure 8 The Lack of Net Capital to Accommodate the Japanese Banking Sector Losses

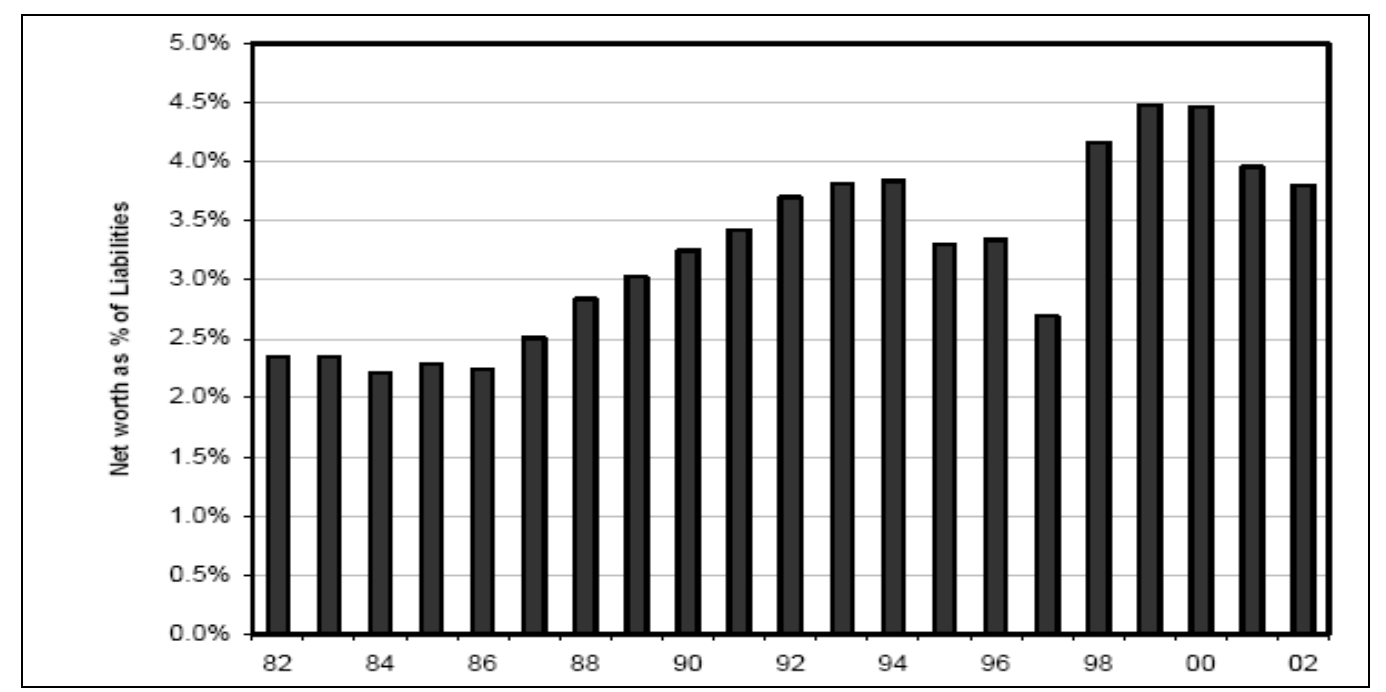

Source: Katz, R., Lessons for US from Japan's Banking Crisis, The Oriental Economist Report No. 212-8684380, March 19, 2009, Retrieved June 27, 2010, http:// www.orientaleconomist.com/ sitebuildercontent/ sitebuilderfiles/oversight_testimony.Pdf. 
Regionally, the fall of the 1990s Japanese Baburu Keizai also resulted Asia's financial crisis between 1997 and 1998. The Asian countries worst affected by the Asian financial crisis were Indonesia, Malaysia, South Korea, Thailand and the Philippines. ${ }^{10}$ In 1997, the average economic growth of the five Asian countries was 5.5 percent compared with 7.4 percent in 1996. In 1998, the average economic growth for these five Asian countries recorded negative growth rates, as shown in Table 11. From July 1997 to July 1998, the Indonesian rupiah suffered losses of more than 90 percent of the value of its currency against the United States dollar. While the Malaysian ringgit, Thailand baht and South Korean won currency suffered a loss of 40 percent of their value.

Table 11 GDP Growth Percent for Countries Affected by Crisis

\begin{tabular}{lccc}
\hline \multicolumn{1}{c}{ Country } & 1996 & 1997 & 1998 \\
\hline Thailand & 5.50 & -0.40 & -8.00 \\
Indonesia & 7.80 & 4.90 & -13.70 \\
Malaysia & 8.60 & 7.70 & -6.20 \\
South Korea & 7.10 & 5.50 & -5.50 \\
Philippines & 5.80 & 5.20 & -0.40 \\
\hline
\end{tabular}

Source: Lan, D. P., The Asian Financial Crisis and Its Implication for Vietnam's Financial System, Visiting Researchers Series No. 11, May, 2000, Retrieved August 28, 2009, http://bookshop.iseas.edu.sg/ ISEAS/Book. jsp?cSeriesCode $=$ VRS11/00\&cCategoryType $=$.

Table 12 Changes in Bank Loan of Japan to Thailand and South Korea

(US\$ billion)

\begin{tabular}{lccccc}
\hline $\begin{array}{l}\text { Country/ } \\
\text { Region }\end{array}$ & $\begin{array}{c}\text { End of 94-end } \\
\text { of } 96\end{array}$ & $\begin{array}{c}\text { End of 96-mid } \\
\text { of 97 }\end{array}$ & $\begin{array}{c}\text { End of 97-end } \\
\text { of 97 }\end{array}$ & $\begin{array}{c}\text { End of 97-mid } \\
\text { of 98 }\end{array}$ & $\begin{array}{c}\text { End of 97-mid } \\
\text { of 98 }\end{array}$ \\
\hline Thailand & 11.10 & 0.20 & -4.60 & -7.10 & -11.60 \\
South Korea & 6.90 & -0.60 & -3.50 & -4.80 & -8.30 \\
\hline
\end{tabular}

Source: BIS, 68th Annual Report. Basle: Bank for International Settlements, 1998.

Note: Data for the Japanese lender may only be available from June 1994.

This was mainly the case because of the reduction in lending by Japanese commercial banks to Asia due to the rising NPLs in Japan and the fall of the stock markets in Thailand and South Korea from 1995 to 1996. So, Japanese commercial banks stopped offering new loans to Thailand and South Korea in 1996 as shown in Table 12. When the Thai financial companies suffered financially in March 1997, Japanese banks acted to bringing out a loan of US\$ 4.6 billion from Thailand in the mid-1997s.

Subsequently, the Nihon Keizai Shinbun reported that seven Japanese banks reduced their overseas loans of $¥ 1.1$ trillion $^{11}$ in six months till 30 September 1997 to achieve the BIS capital requirements. In mid-1998, Japanese bank lending to the Asia-5 was reduced to US $\$ 74$ billion, a decrease of US $\$ 23$ billion over the next 12 months. ${ }^{12}$ Japanese bank

10 Five Asian countries are known as the 'Asian-5'.

$11 ¥ 1.1$ trillion is equivalent to US\$8.6 billion.

12 Sales of Japanese loans has made European banks as the largest lenders in the region with a market share of 41 percent compared to the Japanese conquering only 35 percent. 
lending is one third of the cross-border loans granted to the Asia- $5^{13}$ between mid-1997 and mid-1998. The largest focus of the Japanese bank lending in Thailand was US $\$ 12$ billion, South Korea, US\$8 billion and Indonesia, US\$4 billion. All in all, Japan became a vendor for the largest bank loans to Asia from mid-1997 to mid-1998 (see Table 13 and Figure 9).

Table 13 Changes in Bank Lending to Asia-5

\begin{tabular}{|l|c|c|c|c|c|}
\hline Country/Region & $4 \mathrm{Q} 94-4 \mathrm{Q} 96$ & $1 \mathrm{Q} 97-2 \mathrm{Q} 97$ & 3Q97-4Q97 & $1 \mathrm{Q} 98-2 \mathrm{Q} 98$ & 2Q97-2Q98 \\
\hline Japan & 24.60 & 3.60 & -10.60 & -12.40 & -22.90 \\
\hline North America & 13.50 & -1.80 & -1.60 & -6.00 & -7.70 \\
\hline Europe & 40.60 & 9.60 & -0.50 & -11.50 & -12.00 \\
\hline Others* & 26.60 & 3.00 & -4.00 & -18.50 & -22.50 \\
\hline Total & 105.40 & 14.40 & -16.80 & -48.40 & -65.20 \\
\hline
\end{tabular}

Source: King, M. R. , “Who Triggered the Asian Financial Crisis?' Review of International Political Economy, Vol. 8, No.3, 2001, pp. 438-466.

Note: Data for the Japanese lender may only be available from June 1994.

* Others refer to Switzerland and offshore banking centers in the Bahamas, Bahrain, Cayman Islands, Hong

Kong, Netherlands Antilles and Singapore.

Figure 9 Changes in International Bank Lending to Asia-5

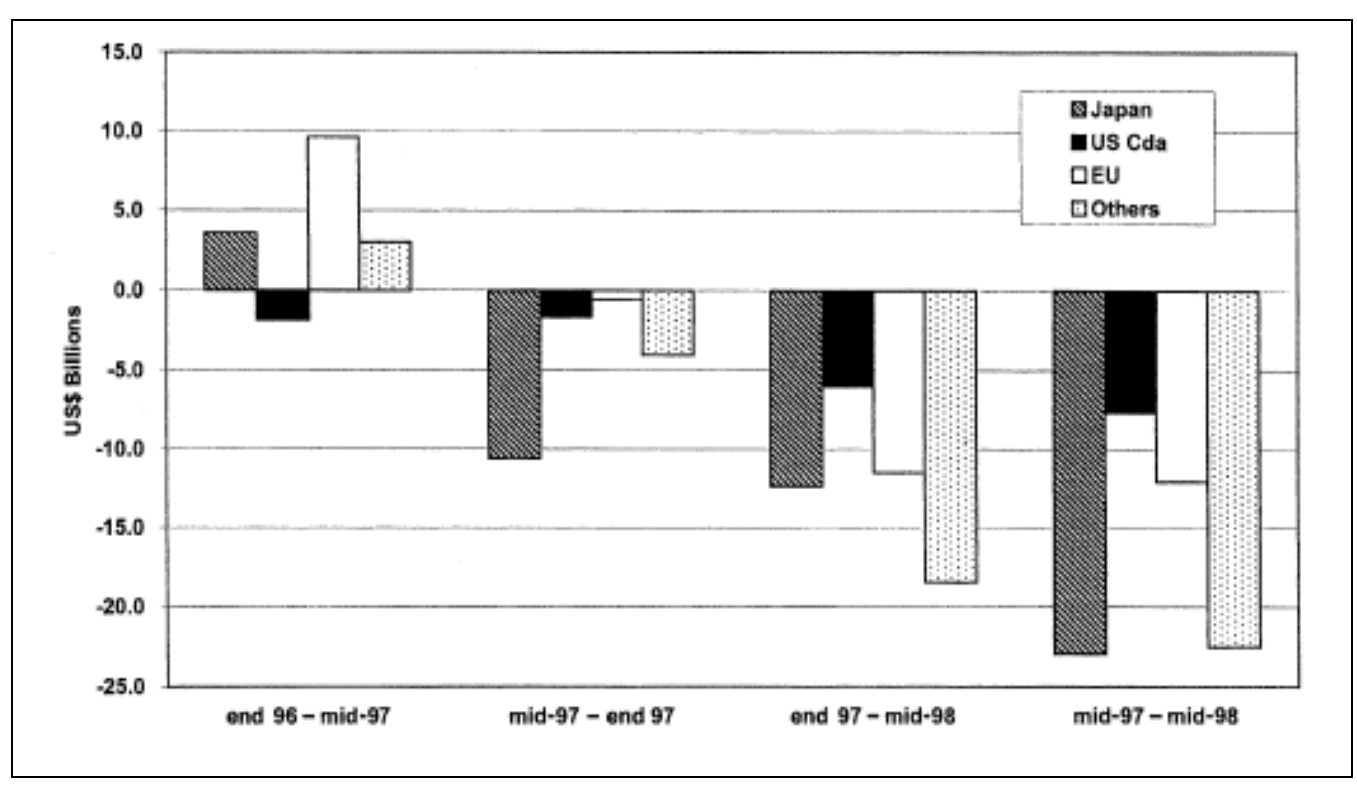

Source: King, M. R. , “Who Triggered the Asian Financial Crisis?' Review of International Political Economy, Vol. 8, No.3,2001, pp. 438-466.

13 Is the major Asian economies that have been affected by the confusion of the financial market since 1997. Asian-5 countries are Indonesia, Korea, Malaysia, Philippines and Thailand. 
Table 14 Trends in Japan's trade with USA, NIE-4, the ASEAN-4 and China between 1995 and First Mid-1998

\begin{tabular}{|c|c|c|c|c|c|c|}
\hline Country/Region & 1995 & 1996 & 1996 & $\begin{array}{c}\text { First } \\
\text { mid-1997 }\end{array}$ & $\begin{array}{c}\text { Second mid- } \\
1997 \\
\end{array}$ & $\begin{array}{c}\text { First mid- } \\
1998 \\
\end{array}$ \\
\hline \multicolumn{7}{|l|}{ World } \\
\hline Export & 442,937 & 412,433 & 422,881 & 205,172 & 217,710 & 192,957 \\
\hline Import & 336,094 & 350,654 & 340,408 & 172,459 & 167,949 & 142,937 \\
\hline Total & 779,031 & 763,087 & 763,289 & 377,631 & 385,659 & 335,894 \\
\hline Trade surplus & 106,843 & 61,779 & 82,473 & 32,713 & 49,761 & 50,020 \\
\hline \multicolumn{7}{|l|}{ USA } \\
\hline Export to USA & 120,859 & 112,277 & 117,669 & 57,437 & 60,321 & 58,655 \\
\hline$\%$ total export & 27.30 & 27.20 & 28.00 & 28.00 & 28.00 & 30.40 \\
\hline import from USA & 75,408 & 79,724 & 76,051 & 38,919 & 37,133 & 35,248 \\
\hline$\%$ total import & 22.40 & 23.00 & 22.30 & 23.00 & 22.10 & 25.00 \\
\hline Total trade with USA & 196,267 & 192,001 & 193,720 & 96,356 & 97,454 & 93,903 \\
\hline$\%$ total trade & 25.20 & 25.20 & 25.40 & 26.00 & 25.30 & 28.00 \\
\hline Trade surplus & 45,451 & 32,553 & 41,618 & 18,518 & 23,188 & 23,407 \\
\hline \multicolumn{7}{|l|}{ East Asia* } \\
\hline Export to East Asia & 186,547 & 174,925 & 171,591 & 84,033 & 87,557 & 65,157 \\
\hline$\%$ total export & 42.10 & 42.40 & 41.00 & 41.00 & 40.20 & 34.00 \\
\hline Import from East Asia & 115,520 & 123,397 & 118,267 & 59,436 & 58,831 & 48,919 \\
\hline$\%$ total import & 34.40 & 35.20 & 35.00 & 35.00 & 35.00 & 34.20 \\
\hline Total trade with East Asia & 302,067 & 298,322 & 289,858 & 143,469 & 146,388 & 114,076 \\
\hline$\%$ total trade & 39.00 & 39.10 & 38.00 & 38.00 & 38.00 & 34.00 \\
\hline Trade surplus with East Asia & 71,027 & 51,528 & 53,324 & 24,597 & 28,726 & 16,238 \\
\hline \multicolumn{7}{|l|}{ NIE-4 } \\
\hline Export to NIE-4 & 111,037 & 101,792 & 101,592 & 49,398 & 52,194 & 40,208 \\
\hline$\%$ total export & 25.10 & 25.00 & 24.00 & 24.10 & 24.00 & 21.00 \\
\hline Import form NIE-4 & 41,219 & 41,006 & 35,389 & 18,173 & 17,216 & 14,728 \\
\hline$\%$ total import & 12.30 & 12.00 & 10.40 & 11.00 & 10.30 & 10.30 \\
\hline Total trade with NIE-4 & 152,256 & 142,798 & 136,981 & 67,571 & 69,410 & 54,936 \\
\hline$\%$ total trade & 20.00 & 19.00 & 18.00 & 18.00 & 18.00 & 16.40 \\
\hline Trade surplus with NIE-4 & 69,818 & 60,786 & 66,203 & 31,225 & 34,978 & 25,480 \\
\hline \multicolumn{7}{|l|}{ ASEAN-4 } \\
\hline Export to ASEAN-4 & 53,579 & 51,243 & 48,214 & 24,751 & 23,463 & 15,256 \\
\hline$\%$ total export & 12.10 & 12.40 & 11.40 & 12.10 & 11.00 & 8.00 \\
\hline Import form ASEAN-4 & 38,379 & 41,841 & 40,812 & 21,244 & 19,568 & 16,357 \\
\hline$\%$ total import & 11.40 & 12.20 & 12.00 & 12.30 & 12.00 & 11.40 \\
\hline Total trade with ASEAN-4 & 91,958 & 93,084 & 89,026 & 45,995 & 43,031 & 31,613 \\
\hline$\%$ total trade & 12.00 & 12.30 & 12.00 & 12.20 & 11.20 & 9.40 \\
\hline Trade surplus with ASEAN-4 & 15,200 & 9,402 & 7,402 & 3,507 & 3,895 & $-1,101$ \\
\hline \multicolumn{7}{|l|}{ China } \\
\hline Export to China & 21,931 & 21,890 & 21,785 & 9,884 & 11,900 & 9,693 \\
\hline$\%$ total export & 5.00 & 5.30 & 5.20 & 5.00 & 6.00 & 5.00 \\
\hline Import from China & 35,922 & 40,550 & 42,066 & 20,019 & 22,047 & 17,834 \\
\hline$\%$ total import & 11.00 & 12.00 & 12.40 & 12.00 & 13.10 & 13.00 \\
\hline Total trade with China & 57,853 & 62,440 & 63,851 & 29,903 & 33,947 & 27,527 \\
\hline$\%$ total trade & 7.40 & 8.20 & 8.40 & 8.00 & 9.00 & 8.20 \\
\hline Trade surplus with China & $-13,991$ & $-18,660$ & $-20,281$ & $-10,135$ & $-10,147$ & $-8,141$ \\
\hline
\end{tabular}

Source: JETRO, Sekai no Bôeki to Nihon. Tokyo: Japan External Trade Organization, 1999.

Note: *Geographical definition of East Asia is consistent with the terms of the Japanese economy ministry which is made up of Northeast Asia and Southeast Asia and in economic consisted of (NIE-4) (South Korea, Taiwan, Hong Kong, Singapore), ASEAN-4 (Malaysia, Thailand, Indonesia, Philippines) and China. 
Japanese export sector changed from the United States to Asia in the mid 1980s. Mutually dependent relationship influenced economic relationship between Japan and Asia. This enabled to fix Japanese trade surplus balance with the United States. Japan is one of the major importing countries of Asia's raw materials and light industrial goods. Share of Japanese imports from Asia showed a continuous upward trend from 12 percent in 1963 to 20 percent in 1975.

After that, the average share of Japanese imports from Asia increased from 25 percent in the 1980s to 30 percent in the 1990s. Large part of Japanese imports from Asia is from the Association of Southeast Asian Nations (ASEAN). Japan dwelved in an average of 60 percent of Southeast Asian imports between 1963 to 1981. But after that, ASEAN's important declined by 1997 as shown in Table $14 .{ }^{14}$ Concurrently, Japanese importation of goods from the Newly Industrial Countries (NIEs) showed an increase from 10 percent in 1963 to 33 percent in 1988 but then fell back to 20 percent in 1997.

In order to promote economic recovery, Japan continued to provide financial assistance to Asian countries that were hit by the 1997 financial and currency crisis through the New Miyazawa Initiative ${ }^{15}$ which was introduced in October 1998. The New Miyazawa Initiative successfully overcame the Asian currency crisis that occurred in 1997 and 1998. In 1999, Asian economies began to improve, as shown by the increase in Southeast Asia's GDP growth rate of 0.8 percent after the GDP growth rate declined by 7 percent in 1998. In 2000, GDP growth rate for East Asia rose higher, namely 2.8 percent as shown in Table 15. Meanwhile, the pace of economic recovery among the Asian countries was different from each other with South Korea and the Philippines growing faster than Thailand, Malaysia and Indonesia.

Table 15 Economic Growth for East Asia and Southeast Asia Nations

\begin{tabular}{lccccc}
\hline & \multicolumn{5}{c}{ GDP growth rate } \\
\multicolumn{1}{c}{ Country/Region } & 1996 & 1997 & 1998 & 1999 & 2000 \\
\hline Southeast Asia & 7.1 & 4 & -6.9 & 0.8 & 2.8 \\
Cambodia & 7 & 2 & 0 & 4 & 6 \\
Laos & 6.9 & 6.9 & 4 & - & - \\
Vietnam & 9.3 & 8.2 & 4 & 3.7 & 4.5 \\
Thailand & 5.5 & -0.4 & -8 & 0 & 2.5 \\
Indonesia & 7.8 & 4.9 & -13.7 & 0 & 2 \\
Malaysia & 8.6 & 7.7 & -6.2 & 0.7 & 2.7 \\
Myanmar & 6.4 & 4.6 & 4 & 3 & 4 \\
Philippines & 5.8 & 5.2 & -0.5 & 2.4 & 4 \\
& & & & & \\
Newly Industrial Countries & 6.3 & 6 & -1.4 & 2.3 & 4.3 \\
Hong Kong & 4.5 & 5.3 & -5.1 & -0.5 & 2 \\
South Korea & 7.1 & 5.5 & -5.5 & 2 & 4 \\
Singapore & 6.9 & 7.8 & 1.5 & 1 & 4 \\
Taiwan & 5.7 & 6.8 & 4.8 & 4.9 & 6.3 \\
\hline
\end{tabular}

Source:Asian Development Outlook 2001. Manila: Asian Development Bank, 2001. 
In 2007, the GDP growth rate for East Asia amounted to 10.1 percent and in 2010, the GDP growth rate for East Asia grew by 5.3 percent as shown in Table 16. So, it is reasonable to argue that Japan should continue to provide financial assistance to countries hit by Asian financial and currency crisis. This is because the economic recovery in Asia would assist in the Japanese economic recovery as shown in Table 17. With reference to Table 17, Japan's exports to the Asian region showed increasing trend from 6.3 percent in 2006 to 11.5 percent in 2007 and 2008. Japan's export situation to the growing Asia region also increased Japan's GDP growth rate from 1.9 percent in 2005 to 2.4 percent in 2007. However, Japan's GDP growth rate experienced a reduction in 2008 and 2009 by 0.6 percent and 6.2 percent respectively as a result of the United States financial crisis that began in 2007.

Table 16 GDP growth rate for the Asia

\begin{tabular}{lcccccc} 
& \multicolumn{1}{c}{$(\%)$} \\
\hline Country/Region & 2005 & 2006 & 2007 & 2008 & 2009 & 2010 (Estimate) \\
\hline Japan & 1.9 & 2.0 & 2.4 & -0.6 & -6.2 & 0.5 \\
East Asia* & 8.1 & 9.1 & 10.1 & 6.6 & 2.9 & 5.3 \\
China & 10.4 & 11.6 & 13.0 & 9.0 & 6.5 & 7.5 \\
South Korea & 4.0 & 5.2 & 5.1 & 2.2 & -4.0 & 1.5 \\
ASEAN 10** & 5.9 & 6.2 & 6.6 & 4.5 & -0.7 & 2.2 \\
India & 9.2 & 9.8 & 9.3 & 7.3 & 4.5 & 5.6 \\
\hline
\end{tabular}

Source: JETRO, 2009 JETRO White Paper on “International Trade and Foreign Direct Investment,' Tokyo: Japan External Trade Organization, 2009.

Note: * East Asia includes ASEAN 10, China, South Korea, Hong Kong and Taiwan.

** Indonesia, Singapore, Thailand, the Philippines, Malaysia, Brunei, Vietnam, Laos, Myanmar and Cambodia.

Table 17 Exports of Japan Based on National and Regional

(Unit: US\$ million, \%)

\begin{tabular}{|l|c|c|c|c|c|c|c|c|}
\hline Country/Region & \multicolumn{2}{|c|}{2005} & \multicolumn{2}{c|}{2006} & \multicolumn{2}{c|}{2007} & \multicolumn{2}{c|}{2008} \\
\hline & Value & $\begin{array}{c}\text { Growth } \\
\text { rate }\end{array}$ & Value & $\begin{array}{c}\text { Growth } \\
\text { rate }\end{array}$ & Value & $\begin{array}{c}\text { Growth } \\
\text { rate }\end{array}$ & Value & $\begin{array}{c}\text { Growth } \\
\text { rate }\end{array}$ \\
\hline Asia & 289,661 & 5.8 & 307,779 & 6.3 & 343,113 & 11.5 & 382,658 & 11.5 \\
\hline China & 80,340 & 8.8 & 92,852 & 15.6 & 109,060 & 17.5 & 124,035 & 13.7 \\
\hline South Korea & 46,880 & 6.1 & 50,321 & 7.3 & 54,199 & 7.7 & 58,985 & 8.8 \\
\hline Taiwan & 43,910 & 4.7 & 44,152 & 0.6 & 44,780 & 1.4 & 45,708 & 2.1 \\
\hline Hong Kong & 36,132 & 2.1 & 36,469 & 0.9 & 38,818 & 6.4 & 39,988 & 3.0 \\
\hline ASEAN 10 & 76,074 & 4.4 & 76,349 & 0.4 & 86,990 & 13.9 & 102,799 & 18.2 \\
\hline India & 3,539 & 16.4 & 4,457 & 25.9 & 6,152 & 38.0 & 7,850 & 27.6 \\
\hline US & 134,889 & 6.4 & 145,651 & 8.0 & 143,383 & -1.6 & 136,200 & -5.0 \\
\hline $\begin{array}{l}\text { Central America and } \\
\text { South }\end{array}$ & 25,112 & 16.0 & 30,574 & 21.8 & 35,063 & 14.7 & 40,684 & 16.0 \\
\hline EU27* & & & & & & & & \\
\hline Middle East & 88,249 & 0.9 & 94,139 & 6.7 & 105,270 & 11.8 & 109,383 & 3.9 \\
\hline World & 16,575 & 14.6 & 19,194 & 15.8 & 26,184 & 36.4 & 33,722 & 28.8 \\
\hline
\end{tabular}

Source: JETRO, 2009 JETRO White Paper on “International Trade and Foreign Direct Investment,' Tokyo: Japan External Trade Organization, 2009.

Note: *Austria, Belgium, Denmark, Germany, Greece, Finland, French, Ireland, Italy, Luxembourg, Portugal, Spain, Sweden, Netherlands, Britain, Cyprus, Czechoslovakia, Estonia, Hungary, Latvia, Lithuania, Malta, Poland, Slovakia, Slovenia, Romania and Bulgaria. 
But in 2010, the GDP growth rate for Japan was expected to grow by 0.5 percent following the Japanese economy recovery as shown in Table 16. This is because Japan and Asia have a co- dependent relationship. Asia is the main importer for Japanese exports while Japan is a major importer of Asia exports. The gradual economic recovery increased Japan's ability to compete with other countries in East Asia and Southeast Asia as shown in Table 17. There is an obvious increase of Japanese exports to developing countries in Central America and South America and the Middle East.

Japan's experience in facing the Japanese Baburu Keizai from 1989 to 2001 provides many important lessons for other countries. The asset prices bubble in 1980s showed Japan the need to have a careful control policy to avoid the financial instability emerging from the development and the fall of asset prices. Careful control policy is needed because Japan is a country where banks dominate its financial industry.

In addition, the implementation of a sound monetary policy in the foreseeable future is important to face potential risks that threaten the Japanese economy. The implementation of monetary policy in the foreseeable future must be able to prevent the risk of inflation in order to avoid the late action taken when the Baburu Keizai emerged. Besides that, late 1998, Japan also promoted a formal supervision and control framework of the banking sector to create a stable macroeconomic environment. This is because there are advantages available from a well designed official deposit insurance system. The final lesson that countries can learn from this experience is the manner in which Japanese banks received support and low cost solutions from the government to overcome the problem quickly.

\section{Conclusion}

The study concludes that the Baburu Keizai faced by Japan in the late1980s not only was the largest in Japan, but it also is a Baburu Keizai that ended with a prolonged economic downturn. In this study, Japan's experience in facing the Japanese financial crisis in the 1990s not only promotd awareness for the Japanese government of the weaknesses of its economic restructuring that threatened Japan's economic growth but it also serves as an important lesson for the United States government that is trying to overcome its own that started in 2008. The situation in the United States financial system remains unsolved and the impact of the financial crisis is not yet known.

For the United States, Japanese experience shows that it needs to learn from the Japanese government's past mistakes and that Washington needs to be quick and take more aggressive actions in its efforts to overcome the financial crisis. In addition, the solutions taken by Japan are expected to benefit Tokyo in the long term as it has the potential to restore and strengthen the almost stagnant Japanese economy. 


\section{References}

\section{Books}

Abrams, K, The Aftermath of an Economic Miracle: An Ethnography of the Japanese Recession, Ml: Ann Arbor, 2000.

Asian Development Bank, Asian Development Outlook 2001, Manila: Asian Development Bank, 2001.

Annual Report on the Family Income and Expenditure Survey 1965-2006, Ministry of Internal Affairs and Communications, Japan, 1965-2007.

Aoki, M., and Patrick, H., The Japanese Main Bank System: Its Relevance for Developing and Transforming Economies, Oxford: Oxford University Press, 1994.

Athukorala, P., C., Crisis and Recovery in Malaysia: The Role of Capital Controls (Second Edition), Cheltenham: Edward Elgar, 2003.

Bank for International Settlements, The BIS 66th Annual Report, Basle: Bank for International Settlements, 1996.

Bank for International Settlements, The BIS 68th Annual Report, Basle: Bank for International Settlements, 1998.

Blinder, A. S., Central Banking in Theory and Practice, Cambridge: Massachusetts Institute of Technology Press, 1998.

Bank Negara Malaysia, The Central Bank and the Financial System in Malaysia, Kuala Lumpur: Bank Negara Malaysia, 1999.

Bouisson, J. M., Japan: The Burden of Success, London: C. Hurst \& Co. (Publishers) Ltd., 2002.

Cargill, T., Hutchison, M., and Ito, T., The Political Economy of Japanese Monetary Policy, Cambridge: MIT Press, 1997.

Deposit Insurance Corporation of Japan, Annual Report 1998: April 1998-March 1999, Japan: Deposit Insurance Corporation of Japan, 1999.

Drees, B., and Pazarbasioglu, C., The Nordic Banking Crises: Pitfalls in Financial Liberalization?, Washington: International Monetary Fund, 1998.

Economic Planning Agency, Annual Report on National Accounts, Tokyo: EPA, 1987.

Eraydin, A., Forming and Bursting Bubbles in Tokyo: Global Cities under the Pressure of Global Forces and the Local Regulation Systems, Japan External Trade Organization: Institute of Developing Economies, 1999.

Ernst, and Young, Global Nonperforming Loan Report 2006, Amerika Syarikat: Global Real Estate Center, 2006.

Funabashi, Y., Managing the Dollar from the Plaza to the Louvre (Second Edition), Washington: Institute for International Economics, 1988.

Gerlach, M., Alliance Capitalism: The Social Organization of Japanese Business, Berkeley: University of California Press, 1992.

Greenspan, A., Achieving Price Stability: A Symposium Sponsored by the Federal Reserve Bank of Kansas City, Toronto: Books for Business, 1996.

Hoshi, T., and Kashyap, A., Corporate Financing and Governance in Japan: The Road to the Future, Cambridge: MIT Press, 2001.

International Monetary Fund, World Economic Outlook Database, October 2010: Nominal GDP List of Countries, Washington: International Monetary Fund, 2010. 
International Monetary Fund, 2009 World Economic Outlook: Rebalancing Growth, Washington: International Monetary Fund, 2010.

Ito, T., The Japanese Economy, Massachusetts: Institute of Technology, 1992.

Japan Real Estate Institute, Urban Land Price Index and National Wooden House Market Value Index, Japan: Japan Real Estate Institute, 2009.

Jain, J., The Housing Boom Preceding the 1980-1982 ‘Depression’, United States: Financial Sense University, 2005.

JETRO, Sekai to Nihon no Bôeki 1998, Tokyo: Japan External Trade Organization, 1998.

JETRO, White Paper on International Trade 1999, Tokyo: Japan External Trade Organization, 1999.

JETRO, Sekai no Bôeki to Nihon, Tokyo: Japan External Trade Organization, 1999.

JETRO, 2008 JETRO White Paper on 'International Trade and Foreign Direct Investment', Tokyo: Japan External Trade Organization, 2008.

JETRO, 2009 JETRO White Paper on 'International Trade and Foreign Direct Investment', Tokyo: Japan External Trade Organization, 2009.

Lincoln, E. J., Japan Facing Economic Maturity, Washington: The Brookings Institution, 1988.

Mikitani, R., and Posen, A. S, Japan's Financial Crisis and Its Parallels to U.S. Experience, Washington: Institute for International Economics Special Report 13, 2000.

Ministry of International Trade and Industry, Japanese Industrial Survey: Macroeconomic Analysis, Japan: Research Institute of International Trade and Industry, 1993.

Musumeci, V., Japan's Bubble Economy: Lessons Learnt, Australia: Macquarie University, 2007.

OECD, OECD Economic Surveys: Japan 1997, Paris: Organisation for Economic Cooperation and Development, 1997.

Oguni, K, Furyoo Saiken Shori no Seijikeizaigaku (The Political Economy of Bad Loan Cleanup), Tokyo: Heigensha, 1995.

Ohlenroth, P., Up from the Ashes: Rebuilding Japan after World War II, United States: The Lucent Library of Historical Eras, 2008. 
Okina, K., Shirakawa, M., and Shiratsuka, S., The Asset Price Bubble and Monetary Policy: Japan's Experience in the Late 1980s and the Lessons (Special Edition), Institute for Monetary and Economic Studies: Bank of Japan. 2001.

Patrick, H., and Rosovsky, H., Asia's New Giant: How the Japanese Economy Works, Washington: The Brookings Institution, 1976.

Sato, K., The Transformation of the Japanese Economy, London: An East Gate Book, 1999.

Sheard, P., Mein Banku Shihon Shugi no Kiki (Main Bank Capitalism in Crisis), Tokyo: Toyo Keizai Shimposha, 1997.

Statistics Bureau, Management and Coordination of Land and Property, Japan, Japan Statistical Yearbook 1998 Ministry of Finance, Tokyo: Printing Bureau, Agency of Japan, 1998.

Stone, D., and Ziemba, W. T., Relationships between Land and Stock Prices in Japan, Vancouver: University of British Columbia dan Tacoma: Frank Russell Company, 1992.

United States Department of Labor, Labor Force Statistics from the Current Population Survey, Washington: U.S. Bureau of Labor Statistics, 2010.

World Economic and Financial Surveys, World Economic Outlook (WEO): Sustaining the Recovery, Washington: International Monetary Fund, 2009.

Yoshikawa, H., Japan's Lost Decade, Japan: International House of Japan, 2000.

Yoshikawa, H., Hoshi, M., Hori, N., Imura, H., Watanabe, T., and Takeda, Y., Kin'yu Seisaku to Nihon Keizai (Monetary Policy and the Japanese Economy), Tokyo: Economic Planning Agency, 1993.

\section{Book Chapters}

Fukao, M.. Japan's Lost Decade and Weakness in Its Corporate Governance Structure. In R. M. Stern, eds. Japan's Economic Recovery: Commercial Policy, Monetary Policy and Corporate Governance. Cheltenham: Edward Elgar Publishing Ltd., 2003, pg. 289-325.

Hoshi,T., and Takeo, A., 'The Impact of Financial Deregulation on Corporate Financing', In P. Sheard, eds. Japanese Firms, Finance and Markets, Melbourne: Addison Wesley Longman Australia,1996, pg. 222-248.

Hoshi, T., and Patrick, H.,' The Japanese Financial System: An Introductory Overview'. In T. Hoshi and H. Patrick, eds. Crisis and Change in the Japanese Financial System, Norwell: Kluwer Academic, 2000, pg. 1-20.

Kato, T., The Asian Financial Crisis and the Southeast Asian Transitional Economies: Impact, Policy Responses and Lessons, Cambodia Development Resource Institute, Cambodian Institute for Cooperation and Peace, Central Institute for Economic Management, Institute of Economics, National Economic Research Institute, 1999.

Saxonhouse, G. R., and Stern, R. M. , 'Japan's Lost Decade: Origins, Consequences, and Prospects for Recovery', In School of Public Policy, eds. Research Seminar in International Economics, 484, Michigan: The University of Michigan, 2002, pg. 1-21.

Ziemba, W.T.,'The Chicken or the Egg: Land and Stock Prices in Japan'. In W.T. Ziemba, W. Bailey and Y. Hamao, eds. Japanese Financial Market Research, Amsterdam: North Holland, 1991, pg. 45-68. 


\section{Journal Articles}

Baba, N., and Hisada, T.,'Japan's Financial System: Its Perspective and the Authorities' Roles in Redesigning and Administering the System,' Monetary and Economic Studies, 20 (2), 2002, pg. 43-93.

Bernanke, Ben, S., Gertler, M., and Gilchrist, S., 'The Financial Accelerator and the Flight to Quality,' Review of Economics and Statistics, 78 (1), 1996, pp. 1-15.

Boot, A. W. A, and Thakor, A. V., 'Self-Interested Bank Regulation,' American Economic Review, 83 (2), 1993, pp. 206-212.

Brainard, W., 'Uncertainty and the Effectiveness of Policy,' American Economic Review, 57 (2), 1967, pp. 411-425.

Browne, L. E., 'Does Japan Offer Any Lessons for the United States?' New England Economic Review, (3), 2001, pp. 3-18.

Calomiris, C., 'Is Deposit Insurance Necessary? A Historical Perspective,' Journal of Economic History, 50 (2), 1990, pp. 283-295.

Corsetti, G., Pesenti, P., and Roubini, N., 'What Caused the Asian Currency and Financial Crisis?' Japan and the World Economy, 11, 1999, pp. 305-373.

Cowling, K., and Tomlinson, P. R., 'The Japanese Crisis: A Case of Strategic Failure?' The Economic Journal, 110 (464), 2000, pp. 358-381.

Daquila, T. C., 'Japan-Asia Economic Relations: Trade, Investment, and the Economic Crisis,' East Asia, 17 (3), 1999, pp. 88-115.

Nyberg, P., 'The Banking Crisis in Finland.' Ekonomiska Samfundets Tidskrift, 48 (3), 1995, pp. 115-120.

Felson, H. M., 'Closing the Book on Jusen: An Account of the Bad Loan Crisis and a New Chapter for Securitization in Japan.' Duke Law Journal, 47 (3), 1997, pp. 567-612.

Goyal, V. K., and Yamada, T., 'Asset Price Shocks, Financial Constraints and Investment: Evidence from Japan.' The Journal of Business, 77 (1), 2004, pp. 175-199.

Hall, M., 'Recent Banking Sector Reforms in Japan: An Assessment.' Asian Business and Management, 6, 2007, pp. 57-74.

Hanazaki, M., and Horiuchi, A.,' 'A Review of Japan's Bank Crisis from the Governance Perspective.' Pacific-Basin Finance Journal, 11, 2003, pp. 305-325.

Hoshi, T., 'What Happened to Japanese Banks?' Monetary and Economic Studies, 19 (1), 2001, pp. 1-30.

Hoshi, T., and Kashyap, A., 'The Japanese Banking Crisis: Where Did It Come From and How Will It End?' NBER Macroeconomics Annual, 14, 1999, pp. 129-201.

Hughes, C. W., 'Japanese Policy and the East Asian Currency Crisis: Abject Defeat or Quiet Victory?’ Review of International Political Economy, 7 (2), 2000, pp. 219-253.

Inaba, N., Kozu, T., Sekine, T., and Nagahata, T., 'Non-Performing Loans and the Real Economy: Japan's Experience.' BIS Papers Chapters, 22, 2005, pp. 106-127.

Ito, T., 'Japanese Monetary Policy: 1998-2005 and Beyond.' Monetary Policy in Asia: Approaches and Implementation, 31, 2006, pp. 105-132.

Ito, T., and Weinstein, D. E., 'Japan and the Asian Economies: A “Miracle' in Transition.' Brookings Papers on Economic Activity, 1996 (2), 1996, pp. 205-272.

Itoh, M., 'Is the Japanese Economy in Crisis?' Review of International Political Economy, 1(1), 1994, pp. 29-51.

Iwata, K., 'Housing and Monetary Policy in Japan.' Bank of International Settlements Review, 96, 2007, pp. 1-12. 
Iwao, N., 'A Design for Transforming the Japanese Economy.' Journal of Japanese Studies, 23 (2), 1997, pp. 399-417.

Kang, K., and Murtaza Syed, 'Overcoming the Global Financial Crisis: Some Lessons from Japan's “Lost Decade'.' CESifo DICE Report, 7 (3), 2009, pp. 13-20.

Kawai, M.,' Reform of the Japanese Banking System.' International Economics and Economic Policy, 2 (4), 2005, pp. 307-335.

King, M. R., 'Who Triggered the Asian Financial Crisis?' Review of International Political Economy, 8 (3), 2001, pp. 438-466.

Kiyotaki, N., and Moore, J., 'Credit Cycles.' Journal of Political Economy, 105 (2), 1997, pp. 211-248.

Krugman, P. R., Dominquez, K. M., and Rogoff, K., 'It's Baaack: Japan's Slump and the Return of the Liquidity Trap.' Brookings Papers on Economic Activity, 1998 (2), 1998, pp. 137-205.

Kuttner, K. N., and Posen, A. S., 'The Great Recession: Lessons for Macroeconomic Policy from Japan.' Brookings Papers on Economic Activity, 2, 2001, pp. 93-160.

Laurence, H., 'Financial System Reform and the Currency Crisis in East Asia.' Asian Survey, 39 (2), 1999, pp. 348-373.

Lee, E. H., 'Review of Fluctuations in Land and Stock Prices in the Japanese Economy.' The Korean Journal of Economics, 16 (1), 2009, pp. 95-122.

Lincoln, E. J., 'Japan in 2001: A Depressing Year.' Asian Survey, 42 (1), 2002, pp. 67-80.

Lincoln, E. J., and Friedman, B. M. , 'Japan's Financial Problems.' Brookings Papers on Economic Activity, 1998 (2), 1998, pp. 347-385.

Lohmann, S., 'Is Japan Special?' Monetary Linkages and Price Stability, Monetary and Economic Studies, 15 (2), 1997, pp. 63-79.

Macey, J., and Miller, G., 'Deposit Insurance, the Implicit Regulatory Contract, and the Mismatch in the Term Structure of Banks' Assets and Liabilities.' Journal des Economistes et des Etudes Humaines, 6 (4), 1996, pp. 1-24.

Milhaupt, C., and Miller, G., 'Cooperation, Conflict and Convergence in Japanese Finance: Evidence from the 'Jusen' Problem.' Law and Policy in International Business, 29, 1997, pp. 1-78.

Murphy, K. M., and Topel, R. H. ,'The Evolution of Unemployment in the United State: 1968-1985.' NBER Macroeconomics Annual, 2, 1987, pp. 11-58.

Nagano, S., "Lessons Learnt from the Mounting Non-Performing Loans in Japan after the 1990s.' Journal of Financial Services Marketing, 11 (2), 2006, pp. 180-189.

Nakamura, H., and Shiratsuka, S., 'Extracting Market Expectations from Option Prices: Case Studies in Japanese Option Markets.' Monetary and Economic Studies, 17 (1), 1999, pp. 1-43.

Nakaso, H., 'The Financial Crisis in Japan during the 1990s: How the Bank of Japan Responded and the Lessons Learnt.' Bank for International Settlements Papers, (6), 2001, pp. 1-76.

Noguchi, Y., "The "Bubble' and Economic Policies in the 1980s.' Journal of Japanese Studies, 20 (2), 1994, pp. 291-329.

Organisation for Economic Co-operation and Development (OECD), 'Historical Statistics, 1960-1993.' OECD Economic Outlook, 2004/2 (76), 2005, pp. 1-237.

Ozawa, T., 'The Rise and Fall of Bank-Loan Capitalism: Institutionally Driven Growth and Crisis in Japan.' Journal of Economic Issues, 33 (2), 1999, pp. 351-358. 
Peek, J., and Rosengren, E., 'Determinants of the Japan Premium: Actions Speak Louder than Words.' Journal of International Economics, 53 (2), 1998, pp. 283-305.

Saito, M., and Shiratsuka, S., 'Financial Crises as the Failure of Arbitrage: Implications for Monetary Policy.' Monetary and Economic Studies, 19 (S1), 2001, pp. 239-270.

Sekine, T., Kobayashi, K., and Saita, Y., 'Forbearance Lending: The Case of Japanese Firms.' Monetary and Economic Studies, 21 (2), 2003, pp. 69-92.

Shinoda, T. ,'Japan's Decision Making under the Coalition Governments.' Asian Survey, 38 (7), 1998, pp. 703-723.

Shiratsuka, S., 'Asset Price Fluctuation and Price Indices.' Monetary and Economic Studies, 17 (3), 1999, pp. 103-128.

Smith, D., 'Loans to Japanese Borrowers.' Journal of the Japanese and International Economies, 17 (3), 2003, pp. 283-304.

Spiegel, M. M. , 'Moral Hazard under the Japanese “Convoy' Banking System.' FRBSF Economic Review, (3), 1999, pp. 3-13.

Stone, D., and Ziemba, W. T., "Land and Stock Prices in Japan.' The Journal of Economic Perspectives, 7 (3), 1993, pp. 149-165.

Swire, P.,'Bank Insolvency Law Now that It Matters Again.' Duke Law Journal, 42 (3), 1992, pp. 469-556.

Tan, H. B., and Yong, C. C., 'The Impact of AFTA on Japan-ASEAN Trade Flows.' Jurnal Ekonomi Malaysia, 41, 2007, pp. 91-109.

Watanabe, W., 'Does a Large Loss of Bank Capital Cause Evergreening? Evidence from Japan.' Journal of The Japanese and International Economies, 24 (1), 2010, pp. 116-136.

Whittaker, D. H., and Kurosawa, Y., 'Japan's Crisis: Evolution and Implications.' Cambridge Journal of Economics, 22 (6), 1998, pp. 761-771.

Yoshitomi, M., 'The “Jusen' Debacle and Japanese Economy.' The School's Business Journal, 96 (7), 1996, pp. 1-18.

\section{Published Conference Papers}

Athukorala, P., C., Malaysian Economy in Three Crises, ANU Working Paper Series No. 2010/12, October, 2010, Retrieved July 05, 2010, http://www.crawford.anu. edu.au/acde/publications/publish/papers/wp2010/wp_econ_2010_12.pdf.

Brooks, D. H., Felipe, J., Hasan, R., and Siregar, R. Y., The Yen Depreciation and Its Implications for East and Southeast Asia, EDRC Briefing Notes Series No. 1, September, 1998. Retrived November 19, 2009,http://www.docstoc.com/ docs/68160234/THE-YEN-DEPRECIATION-AND-ITS-IMPLICATIONS-FOREAST-AND-SOUTHEAST-ASIA\#.

Das, D. K., Implications of the Financial Crisis for Asian Exports, EDRC Briefing Notes Series No. 8, March, 1999. Retrived July 01, 2010, http:/ /www.adb.org/ publications/implications-financial-crisis-asian-exports.

Dekle, R., and Kletzer, K., The Japanese Banking Crisis and Economic Growth: Theoretical and Empirical Implications of Deposit Guarantees and Weak Financial Regulation, Santa Cruz Center for International Economics Working Paper Series No. 1002, March 01, 2003, Retrived October 10, 2009, http:/ / escholarship.org/uc/ item/0t6321ds\#page-1.

Fukao, M., Financial Deregulations, Weakness of Market Discipline and Market Development: Japan's Experience and Lessons for Developing Countries, 
Center for Economic Institutions Working Paper Series No. 2001-17, September 24, 2001, Retrived February 20, 2010, http://hermes-ir.lib.hit-u.ac.jp/rs/ itstream/10086/13968/1/wp2001-17a.pdf.

Horiuchi, A., Financial Fragility in Japan: A Governance Issue, CIRJE F-Series No. CIRJE-F-5, June, 1998. Retrived May 17, 2010, http://www.cirje.e.u-tokyo.ac.jp/ research/dp/98/cf5/contents.htm.

Hoshi, T., and Kashyap, A. K., Will the U.S. Bank Recapitalization Succeed? Eight Lessons from Japan, NBER Working Paper No. 14401, August, 2009, Retrived August 08, 2010, http:/ / www.nber.org/ papers/w14401.

Hoshi, T., Kashyap, A., and Scharfstein, D., The Choice between Public and Private Debt: An Analysis of Post-Deregulation Corporate Financing in Japan, NBER Working Paper No. 4421, August, 1993, Retrived April 15, 2010, http://www. nber.org/papers/w4421.

Hutchison, M. M., Ito, T., and Westermann, F., The Great Japanese Stagnation: Lessons for Industrial Countries, Economic Policy Research Unit Working Paper Series 05-13, December, 2005, Retrived June 26, 2010, http://www.econ.ku.dk/epru/ files/wp/wp-05-13.pdf.

Ishikawa, D., and Tsutsui, Y., Has the Credit Crunch Occurred in Japan in 1990s?, RIETI Discussion Paper Series 06-E-012, 2006. Retrived September 18, 2009, http:/ / www. rieti.go.jp/en/publications/summary/06030010.html.

Ito, T., Japan and the Asian Financial Crisis: The Role of Financial Supervision in Restoring Growth, Institute of Economic Research Hitotsubashi University Working Paper Series 99-10, July, 1999, Retrieved March 25, 2010, http:/ / file. icsead.or.jp/user03/925_184.pdf.

Ito, T., and Harada, K., Bank Fragility in Japan, 1995-2003, CESifo Working Paper Series 1137, February, 2004, Retrieved December 14, 2009, http:/ / www.

ifo-dresden.de/portal/page/portal/DocBase_Content/WP/WP-CESifo_Working Papers/wp-cesifo-2004/wp-cesifo-2004-02/cesifo1_wp1137.pdf.

Kanaya, A., and Woo, D., The Japanese Banking Crisis of the 1990s: Sources and Lessons, IMF Working Paper No. 00/7, January, 2000, Retrieved January 10, 2010., http:/ / www.imf.org/external/pubs/ft/wp/2000/wp0007.pdf.

Karunatilleka, E., The Asian Economic Crisis, House of Commons Library Research Paper Series 99/14, February 11, 1999, Retrieved May 19, 2010, http:/ /www. parliament.uk/documents/commons/lib/research/rp99/rp99-014.pdf.

Katz, R., Lessons for US from Japan's Banking Crisis, The Oriental Economist Report No. 212-868-4380, March 19, 2009, Retrieved June 27, 2010, http://www. orientaleconomist.com/sitebuildercontent/sitebuilderfiles/oversight_testimony. pdf.

Koo, R., and Sasaki, M., Japan's Disposal of Bad Loans: Failure or Success?, NRI Papers No. 151, March 01, 2010, Retrieved March 08, 2010, http:/ / www.nri.co.jp/english/ opinion/papers/2010/pdf/np2010151.pdf.

Lan, D. P., The Asian Financial Crisis and Its Implication for Vietnam's Financial System, Visiting Researchers Series No. 11, May, 2000, Retrieved August 28, 2009, http:/ / bookshop.iseas.edu.sg/ISEAS/Book.jsp?cSeriesCode=VRS11/00\&cCategoryTy pe $=$.

Milhaupt, C. J., Japan's Experience with Deposit Insurance and Failing Banks: Implications for Financial Regulatory Design?, IMES Discussion Paper Series 99- 
E-8, 1999, Retrieved January 09, 2010, http:/ / books.google.com.my/books/about/ Japan_s_experience_with_deposit_insuranc.html?id=tjq3AAAAIAAJ\&redir_ esc $=y$.

Miyagawa, S., and Morita, Y., Lessons from Japan's Prolonged Recession, Tampere Economic Working Papers Net Series 44, September, 2005, Retrieved July 02, 2010, http:/ / www.researchgate.net/publication/29678638_Lessons_from_Japan\%27s_ prolonged_Recession.

Miyajima, H., and Yafeh, Y., Japan's Banking Crisis: Who Has the Most to Lose?, Working Paper Series WIF-03-002, January, 2003, Retrieved February 13, 2010, http:/ / papers.ssrn.com/so13/papers.cfm?abstract_id=558626.

Nagahata, T., and Sekine, T., The Effects of Monetary Policy on Firm Investment after the Collapse of the Asset Price Bubble: An Investigation Using Japanese Micro Data, Research and Statistics Department Working Paper No. 02-3, July 30, 2002, Retrieved April 17, 2010, http://www.boj.or.jp/en/research/wps_rev/ wps_2002/.../cwp02e03.pdf.

Nakamura, R., The Big Cleanse: The Japanese Response to the Financial Crisis of 1990's Seen from a Nordic Perspective, The European Institute of Japanese Studies Working Paper Series No. 149, June 30, 2002, Retrieved July 12, 2010, http:/ / swopec.hhs.se/eijswp/abs/eijswp0149.htm.

Rhodes, J. R., and Yoshino, N., Japan's Monetary Policy Transition, 1955-2004, MPRA Paper Series 4387, 2005, Retrieved October 20, 2009, http:/ / mpra.ub.uni-muenchen. de/4387/1/MPRA_paper_4387.pdf.

Schaede, U., The 1995 Financial Crisis in Japan, UCAIS Berkeley Roundtable on the International Economy Working Paper Series 1071, February, 1996, Retrieved October 15, 2009, http:/ / ideas.repec.org/p/cdl/ucbrie/qt8ks5n2hf.html.

Shiratsuka, S., Asset Price Bubble in Japan in the 1980s: Lessons for Financial and Macroeconomic Stability, IMES Discussion Paper Series 2003-E-15, 2003, Retrieved May 18, 2010, http:/ / www.imes.boj.or.jp/research/papers/english/03-E-15.pdf.

Shiraishi, T., The Asian Crisis Reconsidered, RIETI Discussion Paper Series 05-E-014, March, 2005, Retrieved June 18, 2010, http://www.rieti.go.jp/jp/publications/ dp/05e014.pdf.

Siebert, H., Some Lessons from the Japanese Bubble, Kiel Working Papers No. 919, April, 1999, Retrieved February 15, 2010, http://econpapers.repec.org/paper/ kiekieliw/919.htm.

Tachibana, T., and Sekine, T., Land Investment by Japanese Firms During and After the Bubble Period, Bank of Japan Working Paper Series No. 04-E-2, March, 2004, Retrieved September 26, 2009, http://www.boj.or.jp/en/research/ wps_rev/ wps_2004/data/wp04e02.pdf.

Talley, S., and Mas, I., Deposit Insurance in Developing Countries, World bank working paper No. WPS 548, November, 1990, Retrieved March 17, 2010, http:/ / ideas.repec. org/p/wbk/wbrwps/548.html.

Vattipalli, K., Banking Crisis in Japan, Economics Working Paper Archive Series No. 0411001, November 25, 2004, Retrieved November 03, 2009, http://129.3.20.41/ eps/get/papers/0411/0411001.pdf. 


\section{Newspaper Articles}

Dougherty, C., Stopping a Financial Crisis, the Swedish Way. The New York Times, September 22, 2008, pg. C9.

\section{Articles from Internet}

Bureau of Economic Analysis, National Economic Accounts, 2010, http:/ /www.bea. gov/national/index.htm\#gdp.

Central Intelligence Agency, East and Southeast Asia: Japan, 2012, https:/ /www.cia. gov/library/publications/ the-world-factbook/ geos/ ja.hTml.

Central Intelligence Agency, North America: United States, 2010, https://www.cia. gov/library/publications/the-world-factbook/geos/ us.html.

Deposit Insurance Corporation of Japan, Oparations of DICJ, 2012. http://www.dic. go.jp/english/e_gyomu/e_gyomu.html.

En, W. S., Economy of Japan, 2010, http:/ / www.esri.cao.go.jp/en/sna/data.html\#qe.

Federal Reserve Bank of St. Louis, Japan/U.S. Foreign Exchange Rate, 2010, http:/ / research.stlouisfed.org/fred2/source?soid=1.

Financial Services Agency, Results of the Special Inspections on Major Banks, 2002, http:/ / www.fsa.go.jp/news/newse/e20020412-1.html.

Financial Services Agency, Status of Non-Performing Loans, http:/ /www.fsa.go.jp/ en/regulated/npl/20100205/07.pdf.

Foley, S., US Slashes Interest Rates to New Zero-0.25 Range, 2008, http://www. independent.co.uk/news/business/news/ us-slashes-interest-rates-to-newzero025-range-1193026.html.

Herr, K. E., and Miyazaki, G., The Japanese Non-Performing Loans Problem: Securitization as a Solution, 1999, http:// pages.stern.nyu.edu/ ealtman/JPNsecuritization.pdf.

International Monetary Fund, Economy of Japan, 2010, http:/ / www.imf.org/ external/ pubs/ft/weo/2006/01/data/dbcselm.cfm? G=2001.

Kataoka, T., Bank Crisis: Its Causes and Results, 1996, http://www2.bus.osaka-cu. ac.jp/ kataoka/bcrisis/\#1-2.

Ministry of Foreign Affairs, Japan's ODA Contributing to World Development, 2003, http:/ / www.mofa.go.jp/policy/oda/cooperation/ anniv50/pamphlet/ accomplishment1.html.

Monaneko, Nikkei 225, 2010, http://www.boj.or.jp/en/index.htm.

Nielsen, B., Stagflation, 1970s Style, 2010, http://www.investopedia.com/articles/ economics/08/1970-stagflation.asp.

NPA Services, Inc., The US Unemployment Rate January 1978 to December 1984, 2008, http:/ / www.miseryindex.us/ urbymonth.asp?StartYear=1978-01\&EndYear=198412\&submit1 $=$ Create + Report)

Rosenbluth, F., and Thies, M. F., The Electoral Foundations of Japan's Banking Regulation, 2000, http:/ / ssrn.com/ abstract=1154599.

Rosenbluth, F., and Thies, M. F., The Electoral Foundations of Japan's Financial Politics: The Case of Jusen, 2001, http:/ / ssrn.com/abstract=1158646. 
UFJ Holdings, Keiei no Kenzenka no Tame no Keikaku no Gaiyo (Management Revitalization Plan: Abstract), 2004, http:/ /www.fsa.go.jp/kenzenka/ k_h160924/ ufj_a.pdf.

Watkins, T., Valley, S., and Alley, T., The Recession of 1980-1982 in the US, 2010, http:/ / www.applet-magic.com/rec1980.htm. 